\title{
Sociedad y ciudad en tiempos de Felipe II y la construcción del Virreinato del Perú. Notas sobre los indígenas de Catacaos y la destrucción de Payta por Cavendish (1587)
}

\author{
Artículos originales: SOCIOLOGÍA \\ Recibido: 10/04/2021 \\ Aprobado: 03/07/2021 \\ Publicado: $14 / 10 / 2021$
}

\author{
César Espinoza Claudio \\ Universidad Nacional Mayor de San Marcos \\ cespinozac@unmsm.edu.pe
}

\begin{abstract}
RESUMEN
En esta ocasión buscamos presentar la estructura colonial que construyen los virreyes en Piura y examinar la situación social que vive el pueblo y la comunidad indígena de Catacaos en el último tercio del siglo XVI. La descripción y análisis del ataque y la destrucción de la ciudad y puerto de Payta en 1587 nos sirve como un acontecimiento político que permitirá observar el funcionamiento no solo del sistema virreinal sino también de los patrones y sistemas que adoptaron los indígenas de Catacaos para ajustarse a un sistema político en proceso de construcción. En suma, nos introducimos a conocer el papel de las estructuras coloniales que introduce Felipe II en el corregimiento de Piura y el proceso social que vive Catacaos y otros pueblos indígenas para asegurar el comercio marítimo y terrestre de la plata de Potosí en el norte del Perú y el fortalecimiento de la ciudad de San Miguel de Piura del Villar en 1588.
\end{abstract}

Palabras clave: Payta, corsarios, Piura, Catacaos, tierra, pueblo.

\section{Society and city in times of Philip II and the construction of the Viceroyalty of Peru. Notes on the Indians of Catacaos and the destruction of Payta by Cavendish (1587)}

\begin{abstract}
This paper presents the colonial structure built by viceroys in Piura to examine the social situation experienced by the people and the indigenous community of Catacaos during the last third of the sixteenth century. We describe and analyze the attack and destruction of the city and port of Payta in 1587, which is a political event that allows us to understand the functioning of the viceregal system, the social patterns, and organizations adopted by the indigenous people of Catacaos to adapt to a political system in the process of construction. Finally, we focus on the role of the colonial structures introduced by Philip II in the Corregimiento of Piura. In this sense, we delve into the social process experienced by Catacaos, among other indigenous peoples, to ensure the overland and maritime trade of silver from Potosi in northern Peru and the reinforcement of the city of San Miguel de Piura del Villar in 1588.
\end{abstract}

KeYwords: Payta, corsairs, Piura, Catacaos, land, people. 


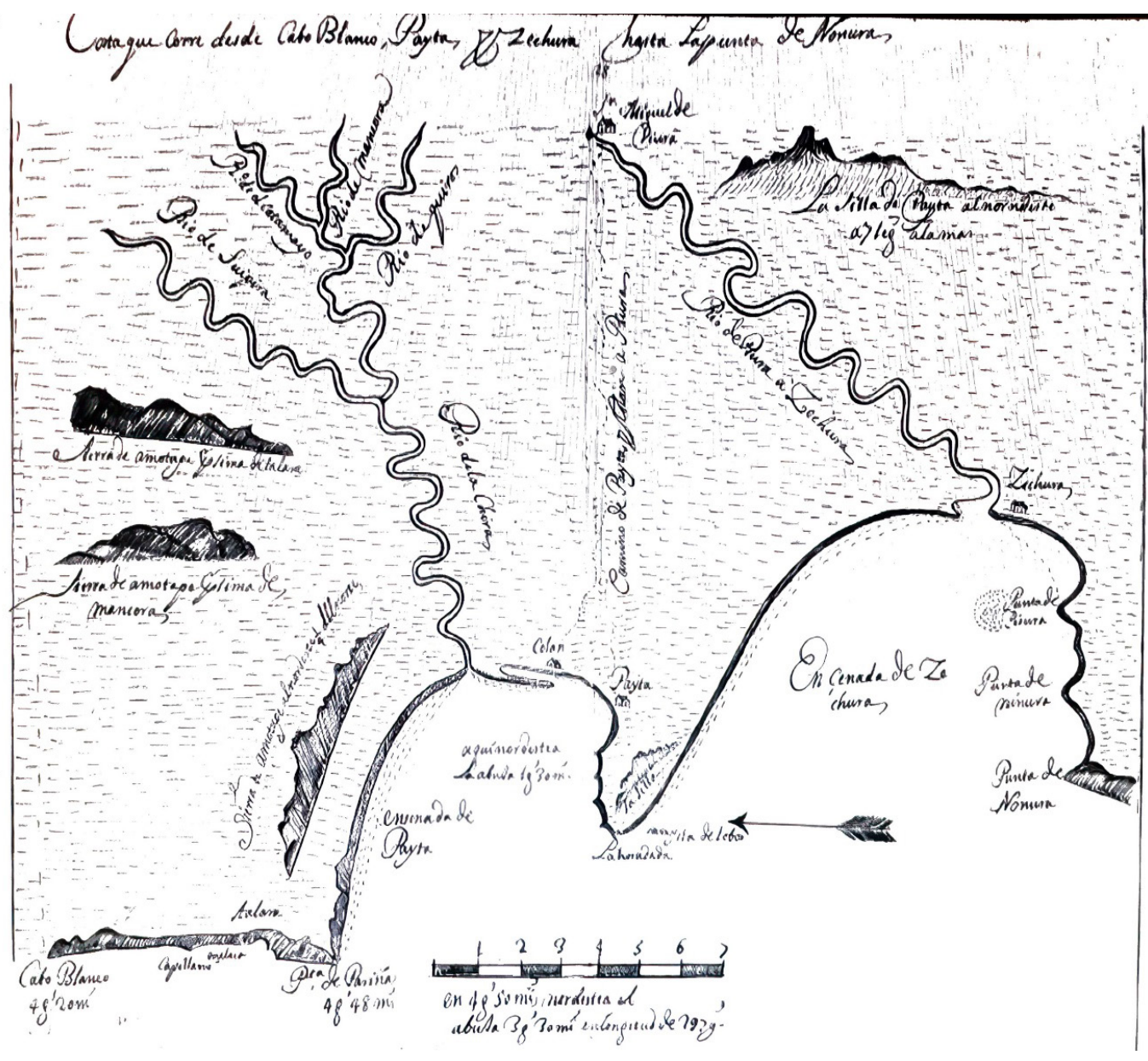

Mapa de la costa del Mar del Sur, entre Cabo Blanco, Payta y Sechura, siglo XVII. Fuente: Queirós (1699?). America del Sur. O. Costas Ca. 1699 (pág. 42). http:// bdh-rd.bne.es/viewer. vm?id=0000001261.

\section{El imperio hispano y la adecuación de Piura y Payta al sistema del corregimiento y el accionar de los corsarios atraídos por la plata de Potosí}

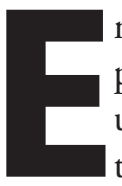

ntre 1532 y 1588 , el espacio territorial comprendido entre Tumbes y Sańa se convirtió en un territorio tallán clave para el movimiento de la conquista y la colonización hispana de un territorio ocupado por los tallanes y chimúes. Desde Panamá llegan numerosas y diversas embarcaciones transportando soldados europeos y gentes de Centroamérica para introducirse a los Andes del Perú (Nueva Castilla). Y bajo otro movimiento inverso que partía desde Arica, Lima y Trujillo toda clase de naves se estacionaban en el puerto y pueblo de Payta. La guerra entre los encomenderos españoles transformó el paisaje agrario y lo reorientó hacia la ganadería y el establecimiento de pequeñas urbes con la función de bases militares de colonización hispana. De tal forma que la primera base urbana bautizada con el nombre de San Miguel (ubicado en Tangarará) por Francisco Pizarro será el modelo de ocupación territorial que impulsa Carlos $\mathrm{V}$ en los Andes del norte del Perú. La historiografía local prohispanista ha reordenado parcialmente estos acontecimientos políticos para presentar a la ciudad de San Miguel de Piura, esta vez instalada a orillas de la cordillera de los Andes, como el aporte progresivo de la cultura española para minimizar la presencia y la derrota político y militar de los tallanes y de las fuerzas militares Yngas que se encontraban estacionadas en esta zona yunga y serrana que hoy conforma el actual departamento de Piura. Entre los escritores locales persistió un exceso de exaltación a lo español y a la imitación de la civilización euroccidental impuesta y difundida por el Estado oligárquico en un espacio regional con una población indígena mayoritaria (Cornejo, 2007; Vega, 1993; Mira, 2018).

En la segunda mitad del siglo XX, entre los escritores y pensadores locales, empieza a sistematizar- 
se el mito y una memoria sobre la existencia de una piuranidad, subordinando y ocultando la vida social multiétnica y multicultural de los tallanes y guayacundos, modelando un discurso del mestizaje que encubre tanto el origen como el funcionamiento de la sociedad y el pueblo tallán que se enfrentó a los Habsburgos, los Borbones y la República oligárquica, y que hoy prosigue resistiéndose al silencio y al olvido de su historia milenaria. Curiosamente un vasco y español como don Joaquin Helguero y Gorgolla, alcalde y hacendado de Piura en 1802 va a descubrir el funcionamiento de la vida andina comunitaria en los valles de Piura y La Chira calificándola de ser una fuerza bloqueadora de la economía mercantil y de la civilización europea que se expandía con los Borbones. Lo cierto es que este funcionario español no quiso entender la subsistencia de otra sociedad que rugía con la economía algodonera que a mediados del siglo XIX serviría para impulsar algunos cambios sociales y políticos que permitieron reducir la segregación, la servidumbre y el esclavismo negrero, la herencia colonial anudada al capitalismo mundial (Betanzos, 1551; Wachtel, 1976).

Respecto al proceso de la dominación española de Piura, nuestra hipótesis de trabajo es que no solo existió un solo proyecto de ciudad como afirman y difunden los escritores locales de Piura, sino que ante el fracaso de Felipe II y de sus virreyes en el Perú para reasentar la ciudad de San Miguel de Piura, ya instalado en el valle de Moscalá (Morropón), un sector de los conquistadores y pobladores criollos levantaron una segunda ciudad a orillas del puerto de Payta, bautizándola con el nombre de San Francisco de la Buenaventura. Esta pequeña urbe marítima tendrá una corta existencia, pues en 1587 será asaltada e incendiada por el inglés Thomas Cavendish acompañado de sus cañones, mosquetes, portaestandartes y corsarios angustiados, para lograr la captura del oro y la plata de El Dorado y las minas de Potosí que habían atormentado sus mentes y sueños (Johnstone, 1990; Edson, 2020).

La pequeńa ciudad de San Miguel de Piura reasentado por Diego de Almagro en el piedemonte andino solo subsistirá casi medio siglo, entre 15341578. Varios indicadores muestran el debilitamiento de esta urbe, empezando por la dispersión poblacional de los tallanes que se trasladaran hacia lo que hoy es El Tacalá, Catacaos y La Munuela, un valle que será ocupado por los tallanes sobrevivientes y a la cual el virrey Francisco de Toledo le otorgará una nueva vida política con la organización de los pueblos y comunidades indígenas de San Juan Bautista (SJB) de Catacaos y San Martín de Sechura. Empiezan a funcionar los Cabildos de Indios y los curacas gobernadores quienes asumen la tarea de reconstruir el antiguo sistema hidráulico y de riego extendido en cuatro leguas y el aseguramiento de los tajamares de El Tacalá y Coscomba en ambas márgenes del rio Lengash, después llamado Piura. En suma, en este siglo de transición, el corregimiento de Piura no tuvo una ciudad-capital entre 1578 y 1587. Durante este tiempo, los virreyes que gobernaron el Perú asentaron una nueva ciudad-puerto que sirvió de capital y centro político: San Francisco de la Buena Esperanza de Payta, que el virrey Conde del Villar lo reemplaza por un nuevo emplazamiento al interior del valle de Catacaos y que será llamado San Miguel de Piura del Villar, para después de 1588 afirmarse con el título de San Miguel de Piura (Espinoza Claudio, 2020:259291; Martos, 1958:158-166).

\section{Ataque y saqueo de la ciudad de San Francisco de la Buena Esperanza de Payta en una mañana del mes de mayo de 1587}

El 30 de setiembre de 1587, después de casi medio año, las autoridades designadas realizaron el levantamiento de los testimonios orales de los vecinos y personas que se encontraron en la ciudad de San Francisco de la Buena Esperanza, puerto de Payta, luego de la invasión y quema de las casas y locales reales ejecutado por las fuerzas marítimas lideradas por el corsario inglés Thomas Cavendish, buscando responsables por lo ocurrido. En esta ocasión, el levantamiento de este expediente escrito se realizó en el pueblo de San Juan, valle de Catacaos, un lugar hacia el cual se habían trasladado los vecinos y encomenderos, pero también los mestizos y mulatos, además de otros grupos de indios que tuvieron que huir asustados por la lluvia de fuego de la artillería y los tremendos ruidos que provocaron los arcabuces y los mosquetes de las gentes que llegaban a orillas del mar de Payta (Archivo General de Indias, 1587. Patronato, 191, R.7, Payta. Probanza sobre la quema de Payta; y Knivet, 2007). 


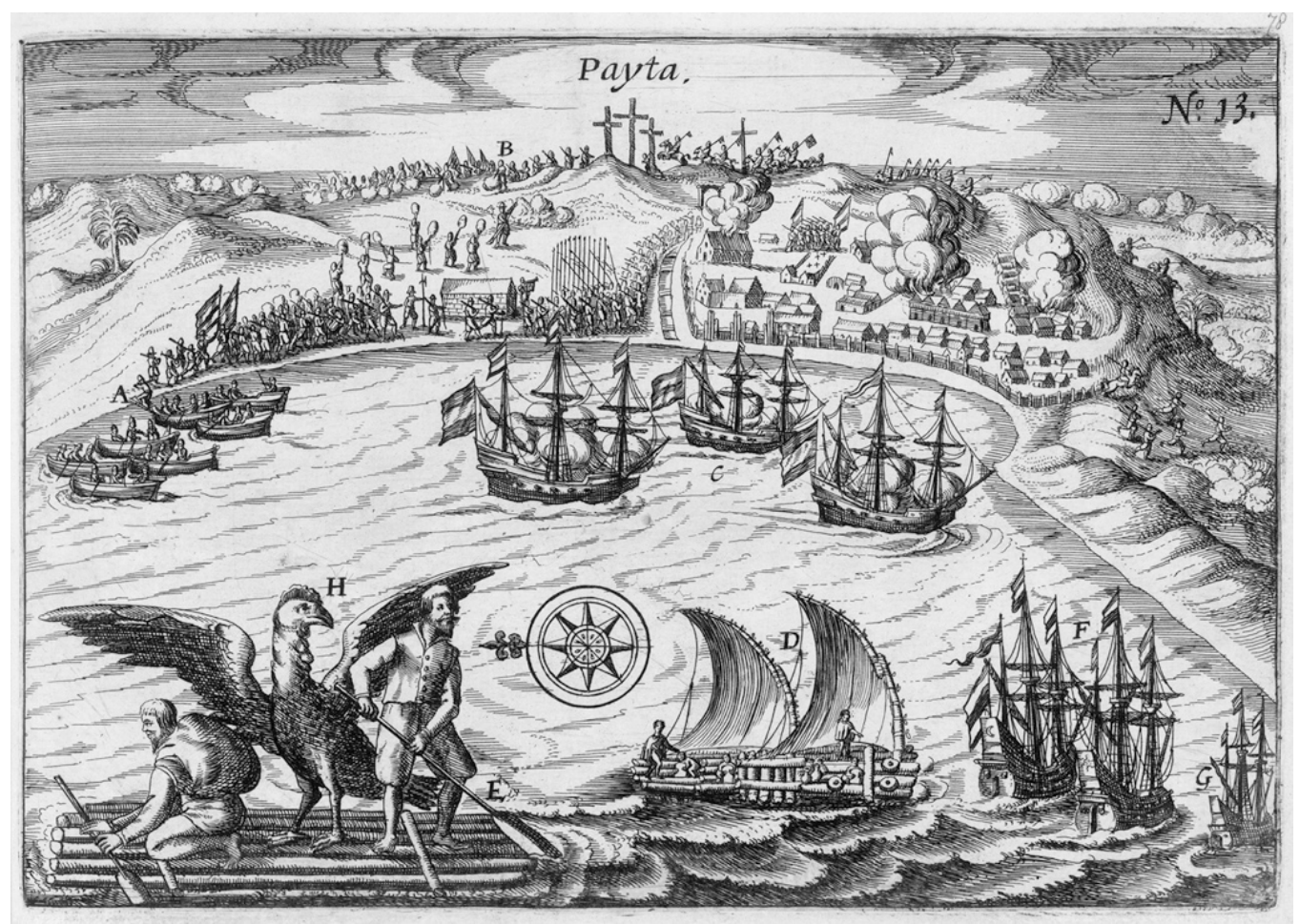

Este dibujo

descriptivo / grabado nos permite imaginar el paisaje donde ocurrió el ataque de Thomas Cavendish a la ciudad y puerto de Payta en 1587. Fuente: van Spilbergen, Joris (aprox. 1568-1620). The East and West Indian mirror: being an account of Joris van Speilbergen's voyage round the world (1614-1617), and the Australian navigations of Jacob Le Maire. Plate No. 13. pág. 206. https:// wellcomecollection. org/works/mmu8kadz
Todo este momento de intranquilidad y de sufrimiento colectivo empezó cuando el virrey del Perú, el Conde del Villar, recibió las noticias de la presencia y el ataque practicado por el corsario Thomas Cavendish en Chile y las villas y pueblos asentados en las orillas y valles del Mar del Sur del Perú. Por tanto, desde la ciudad de Lima se remitió a los pueblos y ciudades de la costa norte del Perú la orden de organizar la resistencia militar a estos ataques por mar, que solo buscaban apoderarse del oro y la plata transportada por las embarcaciones desde la ruta PotosíArica, y también saquear las iglesias, las mansiones de encomenderos, y la gente rica que se había instalado en Arica y Pisco. Aún más, en la costa norte, vecina a la villa de Saña, se había creado y fortalecido una segunda ciudad a orillas del mar bajo el nombre de San Francisco de la Buena Esperanza (SFBE) en el puerto y playa de Payta, pues la antigua ciudad de San Miguel de Piura, ubicada a orillas de la cordillera y en el sitio de Morropón había quedado destruida por la acción de las lluvias y los huaycos provocados por el FEN de 1578, la migración de los indígenas al valle de Catacaos, la destrucción de los sistemas de riego, la propagación de una diversidad de epidemias incontrolables, y la migración forzada de sus vecinos y los encomenderos hacia las orillas del Mar del
Sur (Espinoza Soriano, 2006; Hocquenghem, 1990; Moya, 1994; Cortez, 2018).

El año de 1587 es un tiempo otoñal con mucho calor. En mayo parecía que proseguía el verano y la alegría desbordante de sus gentes se había cortado con el arribo de la noticia enviada desde Lima ordenando la organización de la resistencia a una nueva invasión y ataque de los corsarios ingleses. En esta ocasión la angustia era creciente entre sus gentes, pues esta nueva ciudad fue levantada por los españoles para reemplazar las funciones que había desempeñado la antigua ciudad de San Miguel de Piura, como el garantizar las comunicaciones entre España y el Perú, además de mantener el control social y los negocios mercantiles con la población serrana de Ayabaca, Guancabamba, Guarmaca y Jaén de los Bracamoros.

En la ciudad de SFBE de Payta se vive un momento de fuerte tensión social colectiva porque un grupo de vecinos logró desalojar temporalmente del gobierno local al corregidor Alonso Forero de Ureña. En efecto, un año atrás, los jueces y oidores de la Real Audiencia de Lima habían decretado la salida de la ciudad y de la jurisdicción de la provincia de Piura del máximo representante del virrey Conde del Villar, encargando el mando político temporalmente a su teniente, Gaspar Troche de Buitrago. De esta forma, el vecindario y los 
encomenderos reiniciaron y prosiguieron sus negocios y vivían alegres en este lugar casi solitario rodeado de poblaciones indígenas yungas y de los viajeros marinos que llegaban desde Lima y Tierra Firme. Payta aparentaba ser un lugar quieto y casi abandonado por el rey Felipe II, sin embargo, aquí estaban los encomenderos y oficiales reales que representaban a la autoridad virreinal, asentados en una nueva ciudad ubicado al borde del mar y rodeados por la población indígena de Colán y Sechura asegurando que las naves cargadas de plata de Potosí prosiguieran su viaje a Panamá (Costa, 2016, 2017; Escandell, 1950).

Este colectivo de hombres y mujeres vivían su tiempo gozando del sol y de la brisa marina, pero también en una sensación de bienestar que sería interrumpida con la llegada de las noticias del arribo desde Chérrepe de Thomas Cavendisch y sus naves portadoras de cañones y hombres codiciosos del oro y la plata de los Andes del Perú. ${ }^{1}$

Don Gaspar Troche de Buitrago buscaba cumplir con sus funciones y recorre la ciudad buscando atrapar más tiempo, ordenando que las mujeres y los nińos, junto a las mulas cargadas del oro y la plata que habían acumulado los encomenderos y vecinos ricos, fueran trasportadas al vecino pueblo de Catacaos. A este primer grupo de vecinos luego se sumaron las gentes de mayor edad encargadas de vigilar las mercancías de Castilla y otros bienes de los encomenderos y de los funcionarios reales.

Para todo este tipo de movimiento y transporte de bienes se logró la colaboración de la población indígena de Payta, Colán y Catacaos, pero también de los mulatos y afrodescendientes que residían en la ciudad. En esta dirección, otra tarea que empieza a efectuarse es el levantamiento de una trinchera o pequeño fuerte a la entrada de la ciudad usando la madera y los mecheros para asegurar la vigilancia nocturna. Don Troche Buitrago y la gente que lo acompaña observan preocupados el movimiento de la gente con piel bronceada y los gestos sonrientes de muchos de los participantes, creciendo su intranquilidad, pues los informes que le entregaban podían

Sobre la situación económica, política y ecológica de la costa norte en el siglo XVI se puede revisar las investigaciones sobre Trujillo de Susan Ramírez (1991, 2008), Juan Castañeda (2016), Jorge Zevallos (1985, 1996), Guillermo Figueroa e Iris Vásquez (2020). Para Lambayeque-Saña recomiendo revisar a Teodoro Hampe (1986, 2002:65-83) y Lorenzo Huertas (1987, 1993:145-203). impedir una resistencia de largo plazo. Piensa y calcula cómo superar tal obstáculo con la poca gente que se había concentrado para organizar la resistencia armada. Haciendo números encuentra que solo quedan 45 personas enumeradas que podían participar en la defensa armada de la ciudad, y calculaba que de este grupo solo 20 reunían las condiciones para manejar las armas, montar los caballos y pelear hombro a hombro contra los ingleses. Troche de Buitrago siente que la vida lo atormenta y así vive momentos fugaces de euforia, pero también de desconfianza porque ya un grupo de vecinos había fugado hacia Saña en los días anteriores al ataque.

Troche de Buitrago buscaría organizar y garantizar la resistencia, y siente que lo interesante en las acciones que despliega con los vecinos más comprometidos es la de apurar la construcción de un pequeńo fuerte o trinchera para luego pasar a preparar las armas y acondicionar la pólvora para poder usarla en su momento. En este sentido, observa como un día antes del desembarco de Cavendish, un grupo de vecinos montados a caballo logra recorrer las playas vecinas de Colán y la desembocadura del río de La Chira asegurando que por estos lugares no han llegado los corsarios. A continuación, ordena a un grupo de la gente recoger las cruces que servían de señales en los caminos y en las rutas de los médanos para guiar a los hombres a recorrer los montes y caminos formados a orillas del mar (Schlüpmann, 1991; Espinoza Claudio, 2020).

Troche de Buitrago no puede dormir por la tensión que lo ataca cuando observan como los hombres encargados de la vigilancia desaparecían en la oscuridad y regresaban al día siguiente sin mayores noticias, solo llenos de gestos escépticos y rumores. La ciudad estaba envuelta con el ruido de las olas y las aves, con el movimiento veloz e inevitable de los vientos susurrantes. Así llega un día viernes, tiempo lleno de sensaciones de abandono y malestar evidentes, y es en la madrugada que recibe la noticia de que Cavendish y sus marineros ya avanzaban por el mar, liderados por un batel y sus remeros. Fue este un momento crítico para Troche de Buitrago, un tiempo de desconcierto porque necesitaba saber cuántos invasores venían en las embarcaciones que se dirigían hacia la ciudad. Un sentimiento poco atractivo lo invadía cuando le informaron que los atacantes sumaban cerca de 100 hombres y que llegaban apurados a la playa 
en medio de gritos, llenos de banderas y estandartes, lanzando tremendos ruidos provocados por los cańones que arrojaban bolas de hierro hacia el local de la Aduana y de la Iglesia de la Merced de la ciudad de San Francisco de la Buena Esperanza.

La mañana amaneció en medio de los gases que despliega la pólvora y Gaspar Troche de Buitrago vivirá momentos de sorpresa y decepción, pues ante este alto número de atacantes consideró imposible oponer una resistencia en la trinchera construida a la entrada de la ciudad. Así que sin perder más tiempo ordenó a su gente que suba al tablazo desértico, para dirigirse luego desde este punto hacia el pueblo de Catacaos pues calculaba que ya no era posible oponer mayor resistencia armada. Esta vez, Cavendish ataca usando cańones y hombres portadores de arcabuces y mosquetes, sorprendiendo al pequeño grupo de españoles, quienes, encontrándose asustados en medio del griterío y las balas, ordenaron que los encomenderos, religiosos, vecinos mestizos, mulatos e indígenas abandonaran la ciudad y salvaran sus vidas en el plazo inmediato cruzando el desierto rumbo a Catacaos (Johnstone, 1990).

\section{Thomas Cavendish, los encomenderos y la emergencia de la ciudad de San Miguel de Piura del Villar en 1588}

La reorientación económica del valle serrano de Piura hacia la ganadería provocará el abandono del sistema de riego que se había levantado utilizando el agua que proporcionaban las cuatro afluentes cuyas aguas finalmente confluían en el rio Lengash organizándose las estancias ganaderas de Sancor, Yapatera, Santa Ana y Morropón. Los antiguos campos de labranza de maíz y algodón de estos microvalles como los de Pabur serán convertidos en campos de pastoreo para el ganado vacuno y caprino, mular y en pequeña escala de camélidos como la llama y el guanaco.

A todo esto, se suma el impacto de los ciclos de las alteraciones climáticas con prolongados años secos, y la presencia del FEN en 1578 con epidemias asociadas como la viruela y fiebres desconocidas, que van a impedir la reproducción poblacional de los tallanes y las familias de españoles. Otros factores adicionales son los conflictos/guerras entre los encomenderos, y entre el conjunto de encomenderos con Carlos V, los cuales debilitarán la presencia de las poblaciones tallanes y mitimaes de cañares que todavía subsistían hasta 1588 (Huertas, 1991, 1996, 1997).

Este conjunto de indicadores muestra que el levantamiento de la pequeña urbe de San Miguel en Piura al pie de la cordillera de los Andes resultó también un nuevo fracaso ante la inversión de la lógica económica que predominaba en ese microespacio territorial. En efecto, el abandono de los sistemas de irrigación que dotaron del agua para el fomento de la agricultura del maíz y el algodón será reemplazado por otra economía de las estancias ganaderas para beneficio de los nuevos señores de la tierra en esta región.

En efecto, la imposición de este nuevo modelo económico ganadero provocará la migración de los tallanes hacia las partes bajas, la liquidación de los sistemas de riego y la reducción de la frontera agraria. De esta forma, si a la debilidad demográfica le sumamos la presencia de las epidemias, la explosión de los conflictos sociales entre grupos de gentes de diversas etnias, la destrucción de la ciudad, los caminos, los tambos y los depósitos comunales por el FEN desatado en 1578, el resultado final es la migración casi inmediata de los dueños de tierras, comerciantes, encomenderos y autoridades hacia un territorio mucho más cercano al puerto de Payta. Desde este nuevo punto de colonización marítima -con ayuda del virrey Toledo- empiezan a recuperarse de la destrucción de sus capitales y la mano de obra tributaria, del mancillamiento de su honor y privilegios por la falta de apoyo del rey de España y de virreyes corruptos como el Conde del Villar. Políticamente, el corregimiento de Piura estaba subordinado a la elite y funcionarios asentados en la ciudad de Trujillo. Los encomenderos no vivían en San Miguel de Piura, aquí se asienta un pequeño número de familias dedicadas al negocio del ganado, de los jabones y de los cordobanes, usando la mano de obra indígena y negra esclava. Recién en 1588 con la fundación de San Miguel del Villar de Piura se formaliza a esta pequeña urbe como la capital de un corregimiento que su territorio se extendía desde Tumbes hasta OlmosSaña y un conjunto de pueblos asentados en las serranías de Ayabaca, Huancabamba, Huarmaca y Jaén de Bracamoros. Es una nueva oportunidad para que funcionen los alcaldes y regidores, y tanto los procuradores como los jueces del agua administren este 
recurso para ampliar la frontera agraria y garantizar las parcelas de labranza, señalándose los «Ejidos» municipales que son la base material para generar sus propias rentas y levantar sus edificios con adobes, algarrobo, cañas y piedra.

En buena cuenta, Carlos V y Felipe II apoyaron a Pizarro y al virrey Toledo para levantar una nueva base urbana y reforzar la presencia de los encomenderos, de la Iglesia, y de varias órdenes religiosas que permitieron asegurar un territorio clave de ingreso para el control sociopolítico no solo de la costa norte del virreinato del Perú sino también de la Audiencia de Quito. En medio siglo de colonización, la microurbe de San Miguel (1532) y la de San Miguel de Piura (1534-1578) fracasaron rotundamente porque finalmente se impusieron los intereses de los grupos privados que la orientaron hacia un tipo de economía que desarticuló el funcionamiento de los sistemas de irrigación, los caminos, los tambos y la dispersión de la población hacia otros puntos del virreinato.

Un evento climático como el FEN de 1578 terminó por destruir las pequeñas obras y trabajos realizados por encargo de las autoridades que representaron al virrey Toledo en esta región costeña. Este último año fue también un tiempo de migración de las familias espańolas y los negros esclavos hacia las tierras de la comunidad indígena de Payta, para así, derrotados por la naturaleza, los encomenderos y hacendados lograran reasentarse y empezar a levantar una nueva urbe que les sirviera de bisagra con la economía regional de los Andes del Perú. La clave de todo lo que podían haber avanzado para acumular sus pequeñas fortunas fue la de reconcentrar y de disponer y manejar la mano de obra indígena.

En esta dirección las nuevas autoridades de Lima presionaron a un pequeño grupo de españoles para reconcentrar a la población indígenas pues sin la energía humana que acumulaban los indígenas de Catacaos, Sechura, Colán, Amotape, Pariñas, Payta y Olmos, no sería posible la recuperación económica y la rearticulación de sus redes y lazos comerciales con el mundo y la economía de los Andes del Perú.

En 1587 se encuentran asentados ya en San Francisco de la Buena Esperanza de Payta un grupo de encomenderos, alcaldes y regidores, levantando las bases de una pequeña ciudad marítima en la que sus gentes buscaban nuevamente acumular sus fortunas enlazándose esta vez con las actividades producti- vas y servicios ofrecidos por los tallanes de Sechura, Catacaos y San Lucas de Colán, además de conservar la vigencia y funcionamiento del tráfico mercantil con Panamá y Lima. Hasta esta fecha, en todo el territorio del corregimiento de Piura no existió otra ciudad que funcionara como una cabecera o capital para articular la dominación con los pueblos serranos y amazónicos como Jaén de Bracamoros. Fue un tiempo en que casi toda la economía y la vida política giraba alrededor de esta pequeña base urbana, marítima y multiétnica llamada San Francisco de la Buena Esperanza de Payta, un lugar donde cohabitaban españoles, indios tallanes y negros esclavos.

En la ciudad-puerto de Payta, recién fundada con los españoles, negros e indios que se asentaron después de 1578, se registra la vida política de los alcaldes y regidores, pero sin la presencia del corregidor que representaba al virrey y al rey Felipe II. Hacia Payta se movilizaban en flotas de balsas los tallanes de Sechura y San Lucas de Colán, pueblos dedicados a la pesca y al comercio intra e interregional (Jaramillo, 2019:39-55; Glave, 1991, 1993).

El gobierno del virrey Conde del Villar atraviesa una coyuntura política muy complicada por la presencia casi permanente de piratas y bucaneros que recorren la costa o Mar del Perú buscando capturar a las embarcaciones que transportaban el oro y la plata del rey de España procedente de Potosí y Lima, pero también de los mineros y comerciantes que lo trajinaban hacia Sevilla y otras ciudades mediterráneas. No hay muchos estudios sobre este tiempo histórico, el cual no solo está azotado por los piratas del mar sino también por un grave terremoto en 1586 que provocó serios daños a los pueblos y regiones del centro y norte del virreinato del Perú. Todo parece indicar que este fuerte "temblor" que se produjo de noche en 09.07.1586 provocó un tsunami en la costa de Piura provocando la destrucción total del pueblo de Sechura, cuya población tuvo que trasladarse tierra adentro y buscar que las autoridades le asignen también tierras de labranza para poder subsistir. ${ }^{2}$

2 Levillier, Roberto (1925). Carta del Conde del Villar a Felipe II. Los Reyes, 3 de noviembre de 1586. Informa sobre el terremoto ocurrido el 9 de julio de 1586 que abarca desde Arica a Tumbes. En: Gobernantes del Perú. Cartas y Papeles. Siglo XVI, El Conde del Villar (1548-1587) (Tomo X, pp. 290-291). Madrid: Imprenta de Juan Pueyo. Seiner Lizárraga, Lizardo (2017). Historia de los sismos en el Perú. Catálogo: siglos XV-XVII. Lima: Universidad de Lima. 
Poco después, en una carta del Conde de Villar a Felipe II, desde la ciudad de Lima en 23.04.1587 le comunica sobre la situación que vive Payta "por las pocas y ruinas casas que en el había y deseos que traían los que en ella vivían de pasarlos a otra parte, y así todo es de poca consideración lo que el enemigo ha hecho" (Levillier, 1925. Carta del Conde del Villar, p. $\mathrm{XI})$. La preocupación principal del virrey fue asegurar el envío de la plata de Potosí y los cargamentos de este metal que remitían los comerciantes locales hacia Sevilla; así queda precisado por el Conde del Villar, con una carta dirigida a Felipe II desde la ciudad de los Reyes en mayo 8 de 1587 y dice: "y estando así aguardando los avisos que me vinieses de todas partes estuve ayer jueves siete deste mes de mayo de que en el puerto de la Barranco que es XXIIII leguas de aquí la costa abajo se avían visto tres navíos y una lancha a cinco del dicho mes y la noche pasada hasta la una tuve otros dos avisos dello con certificación de que eran enemigos ingleses de personas de crédito que los afirman y averlos reconocido por tales aunque no habían saltado en tierra y así lo que toca a la plata está asegurado porque para ello a habido demasiado tiempo y he tenido aviso del dicho presidente Cardenas de que llegó a Payta a tomar agua a XX del pasado y del licenciado Calderón de la dicha Payta en carta de XXVI del de que viniendo de Panamá encontró sobre Cabo Blanco que es treinta leguas o más de Payta y que llevaba muy buen tiempo y que al mismo llegarían a Panamá para que pudiesen los galeones llevar la dicha plata con las demás porque aunque yo había enviado aviso al general dellos de cómo le quedaba despachando para que la esperase todo el tiempo que pudiese no contraviniendo a la orden que tuviese de vuestra majestad no me daba menos cuidado que se hubiese ido sin ella por ser tanta cantidad y la falta que haría para el servicio de vuestra majestad y porque no habiéndola de llevar ahora los dichos galeones estuvieran mejor aquí que en Panamá y conforme a lo referido parece ya que estos enemigos han pasado y conforme a lo referido parece ya que estos enemigos han pasado a este Mar que todo lo de hasta aquí ha sucedido bien bendito nuestro Señor por ello que es quien lo ha hecho» (Levillier, 1925. Carta del Conde del Villar, pp. 290-291).

Fue en esta ocasión que don Alonso Forero de Ureña había sido obligado a salir de la provincia por una orden real emitida por el virrey Conde del Villar, pues Forero había sido denunciado por un grupo de vecinos locales de cometer muchos abusos y tropelías insoportables ligados a los negocios regionales. Va a ser en este contexto y los otros que hemos seńalado que les llega una noticia alarmante desde Lima, que el bucanero Thomas Cavendish se dirigía velozmente hacia el norte del Perú para tomar y asaltar las ciudades costeñas buscando el oro y la plata de Potosí y de los encomenderos. Así, ante el peligro de esta invasión un pequeño grupo de españoles planearon y decidieron resistir el ataque primero desplazando a las mujeres y a los niños al pueblo indígena de SJB de Catacaos, y de igual forma, a los más ancianos a quienes encargaron trasladar en burros y mulas todo el tesoro acumulado en oro y la plata, y también toda clase de ornamentos y sus joyas más apreciadas ${ }^{3}$.

De tal forma que, en el puerto de Payta, solo quedaron medio centenar de gentes que van a prepararse para la resistencia del corsario irlandés. En este trajinar de guerra, entre los encomenderos funciona la memoria y recuerdan que este tipo de ataques no era nada nuevo para esta región pues antes había ya llegado Francis Drake (1579). Lo interesante de los preparativos realizados es la de encontrar la presencia de los religiosos mercedarios movilizándose y desplegando sus acciones cristianas de resistencia a la invasión de los luteranos. Para esta fecha, la ciudad de San Francisco de la Buena Esperanza funcionaba como una pequeña base urbana y militar hacia la cual confluían los comerciantes de la villa de Saña, Loja, Cuenca y también de las gentes tributarias indígenas (Diez, 2006:107-127).

La dinámica de las estancias ganaderas del corregimiento de Lambayeque y de la villa de Saña también se habían articulado a la economía estanciera de Piura, demostrando una singular dinámica territorial y social que permitirá, a esta segunda ciudad fundada por los españoles, avanzar en el objetivo de asegurar una pequeña base urbano-marítima para proseguir la acumulación económica, apoyados por la doctrina cristiana y la evangelización que extendían los mercedarios. En esta dirección, un pequeño grupo de poder compuesto por encomenderos y mercedarios apoyados por hacendados y comerciantes buscaban responder a la misión que tenía el virrey Conde del

3 Ver: Archivo General de Indias, 1593. ES.41091.AGI/24//Lima, 210, N. 3. 
Villar de reasentar una nueva ciudad en esta parte del virreinato del Perú. Se trata entonces de un objetivo estratégico económico y militar que fracasó pues esta ciudad cristiana y virreinal casi desapareció con la acción armada de Cavendish y sus soldados.

Lo que ocurrió después es interesante para la historia regional, pues los encomenderos y religiosos habían terminado fugándose a la pequeña villa de SJB de Catacaos para que, luego apoyados y recuperados de la acción de la guerra, gestionaran ante el virrey Conde del Villar, la refundación de la ciudad de San Miguel de Piura, en las tierras y valle que ocupaban los indígenas tributarios de Catacaos, y que otro pequeño grupo de indígenas cańares se reasentasen en lo que después sería el barrio y la capilla de San Sebastián, en el sitio de El Chilcal y también en el sitio vecino a Catacaos, llamado posteriormente Simbilá (Camino, 1982; Echeandía y Renate, 1990).

Para la ejecución de esta acción política los encomenderos y religiosos tuvieron el apoyo de la población organizada en parcialidades en Catacaos, ubicando a la ciudad en una red de caminos que la articulaba al valle de La Chira y a la sierra de los Guayacondos. Uno de los principales participantes de esta pequeña historia de la ciudad de San Francisco de la Buena Esperanza y luego de la ciudad refundada de San Miguel de Piura del Villar (1588) es don Hernando Troche de Buitrago, un español que transitará de ser encomendero y alcalde, a convertirse en gran propietario y dueño de las tierras de la hacienda de Tangarará en el valle de La Chira y otras propiedades en el valle de Catacaos (Cruz Villegas, 1982: 120-123).

Fue en este transitar histórico que nuevamente se reasienta una nueva ciudad bautizada con el nombre de San Miguel de Piura del Villar, una pequeña urbe que subsistió financiada con el trabajo y los recursos que le proporcionaron las tierras de SJB de Catacaos. Este proceso demandó negociaciones con los caciques y tributarios indígenas dedicados al cultivo del maíz y el trigo, que serán procesados en los molinos de piedra movidos temporalmente con las aguas que bajaban por el río Piura. Esta vez, se organiza una nueva economía agrícola indígena, que empieza a convivir con la economía de las estancias ganaderas, las fábricas y las tinas de jabón que se articularon con Saña y Trujillo hasta un nuevo ciclo que se desplegará hasta la llegada del FEN de 1728, un evento climáti- co que destruirá con mucha fuerza el capital urbano y rural acumulado durante un poco más de un siglo.

Ahora bien, a partir del año de 1588 es que se refuerza la condición fronteriza de San Miguel de Piura, una base urbana hispánica que no pudo subsistir en el piedemonte de los Andes de Morropón y tampoco a orillas del mar y puerto de Payta. La política de colonización española impulsa la formación de una nueva elite que gobierne esta región; tarea estratégica urgente que exigen cumplir los virreyes desde Lima, enviando a un corregidor y designando a los encomenderos y reinstalando la economía de los tributos y diezmos. En el corto plazo, esta política y proceso fue una cuestión central para el virrey que gobernaba desde la ciudad de Lima, cuyo cumplimiento era vital para asegurar la formación y asentamiento definitivo de una ciudad halagada por la pluma de historiadores como Miguel Maticorena (1999), José Antonio del Busto (1969), Guillermo Lohmann Villena (1979), Juan José Vega (1993) y Juan Paz Velásquez (1986).

El acontecimiento de la destrucción de la ciudad de San Francisco de la Buena Esperanza -por Cavendish, sus naves y cañones de guerra- permitió que se impusieran las transformaciones impulsadas por el virrey don Francisco de Toledo en Piura. Se vivió una transformación económica importante con la consolidación de la economía de las estancias ganaderas. El proyecto de recuperar el tajamar de El Tacalá para usarlo en la ampliación de la frontera agraria quedó colapsado con el FEN de 1578. El Virrey Conde del Villar tuvo que apoyar el nuevo proyecto planteado por los encomenderos y religiosos de refundar la vieja ciudad de San Miguel de Piura para salir de la crisis y el estancamiento económico. La primera obligación de la gente de Piura fue rearticular el contrato social de convivencia con la elite indígena de Catacaos para recuperar la mano de obra tributaria, de los mitayos y trabajadores colonos, y luego empezar a organizar la formación de la gran propiedad territorial. Paralelamente, se reconstruyeron los caminos, puentes y tambos; y se combatió las epidemias y plagas que habían azotado a los pueblos y las propiedades rurales.

De esta forma, con la llegada de Thomas Cavendish (1587), tenemos como efecto indirecto la aceleración de un proceso de transformación económica impulsado por el virrey don Francisco de Toledo, quien usó las encomiendas y las visitas para 
manejar una mejor distribución de la población yunga y serrana en función de la economía de las estancias ganaderas.

En adelante, se vivirá un nuevo tiempo histórico y un proceso de transformación, adaptación y cambio que sería interrumpido en 1728 por las lluvias e inundaciones en toda la región de Piura. SM de Piura evita aislarse en la región y buscar articularse mediante una economía colonial de exportación de minerales. Durante este tiempo el virrey exige cumplir con la misión asignada de asegurar la continuidad del movimiento mercantil de las embarcaciones marinas que se estacionan temporalmente en Payta, ello involucró también garantizar a los viajeros y pasajeros el suministro de alimentos, leña, agua, y toda clase de provisiones para la subsistencia y continuidad de los barcos y las flotas anuales. El camino real de los Yngas o Capac Nan funcionó cruzando el desierto de Olmos, Sechura, Payta y Tumbes, para abrirse por la sierra de Ayabaca y conectarse con Loja y Quito (Hocquenghem, 1994:1-67).

En efecto, con la economía de la estancia emergió paralelamente una pequeña agricultura de la cańa de azúcar, trigo, maíz y algodón, no solo para el consumo interno, sino también para abastecer a las embarcaciones marinas, ya sea bajo la forma de productos como harinas, biscochos, tejidos, brea, cecinas, diversos productos textiles indígenas y pescados ofertados por los pueblos de Colán, Sechura y Catacaos.

Para finales del siglo XVI todavía convivirán los cultivos del maíz, trigo y algodón; lo que ocurre en este tiempo es la recuperación de zonas de cultivo de manera dispersa en las tierras de orilla y de islas en los ríos Piura y La Chira. En una pequeńa escala también se siembra y cosecha la vid para el consumo de las familias españolas, y se empieza a procesar la cańa de azúcar en trapiches de madera para producir el aguardiente local, la chancaca y las mieles.

La guerra de los encomenderos, la destrucción de la ciudad de San Francisco de la Buena Esperanza y la recuperación de San Miguel de Piura del Villar permitirán la formación de zonas agroganaderas alrededor de estas microurbes, cuya producción se orienta al consumo de la gente criolla y mestiza de las ciudades, pero también de las masas poblacionales concentradas en pueblos como Colán, Catacaos y la villa de Saña. Es a partir de estos ańos que empieza a privatizarse las tierras indígenas y a formarse los grandes latifundios como Tangarará por don Francisco Sojo y que luego los reconcentrará don Francisco Xavier Fernández de Paredes, el marqués de Salinas.

Desde el año de 1588 en adelante, empieza a formarse un mercado interno, organizando otras grandes propiedades rurales señoriales que van a permitir la formación de una elite hegemónica integrada por españoles y los cacicazgos indígenas al interior de los valles que disponen de agua permanente en sitios de la desembocadura de los ríos. Con el apoyo del virrey de Lima se asienta ahora la hegemonía política de SM de Piura, aquí residirá el corregidor y los alcaldes y regidores encargados de cobrar los tributos y a recaudar los diezmos otorgándole un peso económico superior al que detentaban los pueblos indígenas en su conjunto. La novedad en este tiempo es que los encomenderos residirán fuera de la ciudad y el valle de Piura. En este proceso se incrementará la presencia de los negros esclavos, del peonaje indígena asalariado, y del sistema de colonato al interior de las grandes propiedades. Las visitas y las composiciones de tierras de 1595, 1614 y 1723 permitirán la formación de un sistema de hacienda y de estancias ganaderas cuyos propietarios empiezan a residir temporalmente en sus viviendas y calles construidas paralelamente al río Piura.

Desde la primera mitad del siglo XVI, los negros esclavos provenientes desde Panamá participarán en el crecimiento de la agricultura de panllevar que se organiza en las tierras de "Ejidos» que rodean a la ciudad de Piura. La mano de obra esclava realiza trabajos agrícolas, pero también participa de los contratos para brindar servicios en calidad de domésticos y guardianes de las mansiones señoriales que comienzan a dar forma a las primeras calles cercanas al río Piura.

En otros lugares, como en el piedemonte cordillerano que va desde Tambogrande hasta Morropón, convivirán la ganadería de carne, la producción de cueros, y el microcultivo de la caña de azúcar. No faltan tampoco parcelas y huertos con otros cultivos de cereales como el trigo, la cebada y los frijoles, además de frutales y verduras. Los bosques de algarrobo y de zapote crecen y se expanden entre los médanos de arena en Pabur, Guangalá, Chapica y Yapatera.

Durante esta etapa revive el contacto que articula a las gentes de Loja y Cuenca. Desde estos pueblos andinos llegaban los textiles, la harina de trigo y al- 
gunas cantidades de oro y plata. Este es un momento donde todavía los volúmenes totales de estos productos son pequeños. De igual forma, ocurre un proceso semejante por el sur con la villa de Sańa y la ciudad de Trujillo. En este último circuito se practica el contrabando del tabaco y textiles venidos de Europa y China.

Los ciclos de sequía entre los años de 1588 y 1728 requieren de mayor estudio. El tiempo seco se caracteriza por sus calamidades y hambrunas, movilizando a la gente de los valles hacia lugares explotables con puquios o jagüeyes, como las tierras de orilla a lo largo de los ríos y de sus afluentes. Las cosechas muchas veces son interrumpidas por la dureza de la sequía, la presencia de plagas y la proliferación de animales roedores (ratas).

Las epidemias asustan a las poblaciones, las cuales migran hacia las ciudades en busca de medicinas. Este es el tiempo en el que se vive la peste bubónica, la viruela, la lepra y las enfermedades venéreas. La población quedará mermada y el comercio se paraliza. En este periodo de marasmo y triunfo de los médanos desérticos se presentarán los Betlemitas durante el siglo XVII para construir su hospital y capilla casi en el centro de la ciudad de SM de Piura.

La sensación de miedo es casi permanente entre las poblaciones y gentes de varios colores porque en Payta no dejan de llegar otras naves de corsarios y piratas que amenazan con destruir a la ciudad, bloquear los puertos y las rutas de comercio. En la memoria de las gentes de SM de Piura quedó grabada la toma y destrucción de la ciudad de San Francisco de la Buena Esperanza y puerto de Payta. El fantasma de Cavendish navega en las mentes y las palabras de los habitantes, pues todavía recuerdan la destrucción de la iglesia, los almacenes de los grandes comerciantes españoles y de la Real Hacienda del rey de España. Desde San Miguel de Piura del Villar y del puerto de Payta se vigilará el mantenimiento del monopolio ibérico. Sin embargo, los vigías sechuranos informan que el mar está cruzado por mercaderes con naves mucho más veloces rumbo a Panamá o Trujillo (Costa, 2016, 2017).

En el expediente inédito que ahora publicamos encontramos la preocupación del virrey por encontrar una explicación de lo ocurrido en la ciudad de San Francisco de la Buena Esperanza de Payta, pues esta pequeña villa marítima se encontraba sin la pre- sencia del corregidor mientras su defensa fue organizada por el teniente y encomendero don Gaspar Troche de Buitrago. En este manuscrito se registra la preocupación permanente del virrey Conde del Villar respecto a la defensa de la ciudad de San Francisco de la Buena Esperanza. Los testimonios de quienes estuvieron allí confirmaban que la resistencia de los comerciantes y encomenderos no había sido eficiente, pues entre estas gentes se presentaron casos de cobardía, miedo, traición y angustias colectivas ante la fuerza militar de Cavendish en 1587.

El primer problema que enfrentó el grupo que dirigió la resistencia fue la deserción. Se informó que de la media centena que se presentó como voluntaria para la defensa armada, muchos de estos eran viejos y otros sin preparación militar. Los que pudieron levantar esta vez una pequeña trinchera a la entrada del puerto -la mismo que fue destruida por las bolas de fuego que disparaban los cańones de la nave mayor por Cavendish- fueron pocas personas, miembros de la casta indígena, mestiza y mulatos. Varios testigos afirman que el ataque empezó en las horas de la madrugada, en las cuales los corsarios tomaron la ciudad sin mayores resistencias porque sus habitantes fugaron hacia el tablazo apoyados en sus caballos y mulas, y que solo se dedicaron a dar voces de que no llegarían a ningún trato o solicitud de cupo para que no destruyeran las casas de los vecinos y los templos religiosos. De esta forma, la fuerza militar que tomo la ciudad llegó a los cien marinos y que éstos llevaron a cabo la tarea empleando varios botes, muchas banderas, portaestandartes y griterío al momento de tomar la orilla del mar y el puerto de Payta.

En el expediente revisado se registra que casi todos los testigos declaran que, en esta ocasión, un grupo de vecinos se mudó a la villa de Sańa y que otro grupo finalmente, después de salvar sus equipajes y otros menesteres, terminó refugiándose en las casas del pueblo de Catacaos buscando reunirse con sus familiares y amigos. En esta acción de guerra los vecinos de Payta vivieron una intensa emoción pues al gran griterío se sumaron los pregones y los tañidos de las campanas, pero que esta sonora acción, ante los cañones de Cavendich, no sirvió de nada para resistir a la invasión. Por tanto, los alcaldes y los vecinos montados en sus caballos optaron por refugiarse en el tablazo desértico, y desde allí escondidos, miraron con mucha furia y rabia, la práctica del saqueo, pillaje 
e incendio de la ciudad por los soldados y marinos ingleses.

Revisando los daños materiales sobre la ciudad de San Francisco de la Buena Esperanza se encuentra que éstos fueron trágicos, pues las casas y los templos fueron saqueados y quemados. La iglesia de la Merced terminó siendo destruida, sus imágenes y retablos fueron robados, de igual forma ocurrió para la pila de bautismo y el cáliz, así como las campanas, el vino y los alimentos que se conservaban para el mantenimiento de la iglesia mercedaria. Lo que ocurrió después fue el abandono de esta ciudad, debido a que en ella se priorizó la construcción de un pequeño fortín. Nuevamente tuvieron que pasar muchos años para que, acompañados de los indígenas, los comerciantes y marinos que se estacionaban a orillas del mar inicien la reconstrucción del puerto de Payta. Desde la ciudad de Lima, fue casi inexistente el envío de recursos para reconstruir una nueva ciudad que busque engancharse a la lógica mercantil, el Estado virreinal tampoco reconstruyó las viviendas, y disminuyó la inversión en obras públicas para la construcción de muros y/o acequias para derivar las aguas en tiempo de lluvias. En Payta convivieron, por un lado, un grupo pequeńo de indígenas organizados en el modelo de la comunidad con su Cabildo de
Indios, y de otro lado, un grupo de españoles, criollos, mestizos y negros esclavos que vivirán del movimiento comercial marítimo en el sitio del puerto en el que se van formando algunas calles y locales de almacenamiento.

\section{Características del pueblo y las gentes de Catacaos, un grupo humano que vive desafiando el desierto y un río con sequias y crecientes tormentosos en el tiempo milenario}

Durante el gobierno de Francisco de Toledo se había reorganizado el sistema virreinal, imponiendo el gobierno de los corregidores, los encomenderos, la iglesia y las órdenes religiosas para construir un nuevo espacio regional gobernado desde una pequeña urbe, al pie de la cordillera de los Andes (en San Miguel de Piura, territorio de Moscalá-Morropón), y yunga, a orillas del mar (San Francisco de la Buenaventura de Payta). La población de los guayacundos se había debilitado en los valles cordilleranos de Ayabaca, Guancabamba y Guarmaca. Las reducciones y reconcentraciones de la población estuvieron enfocadas en la zona yunga, alrededor y entre el puerto de Payta y Tumbes, un territorio cruzado por el camino real de

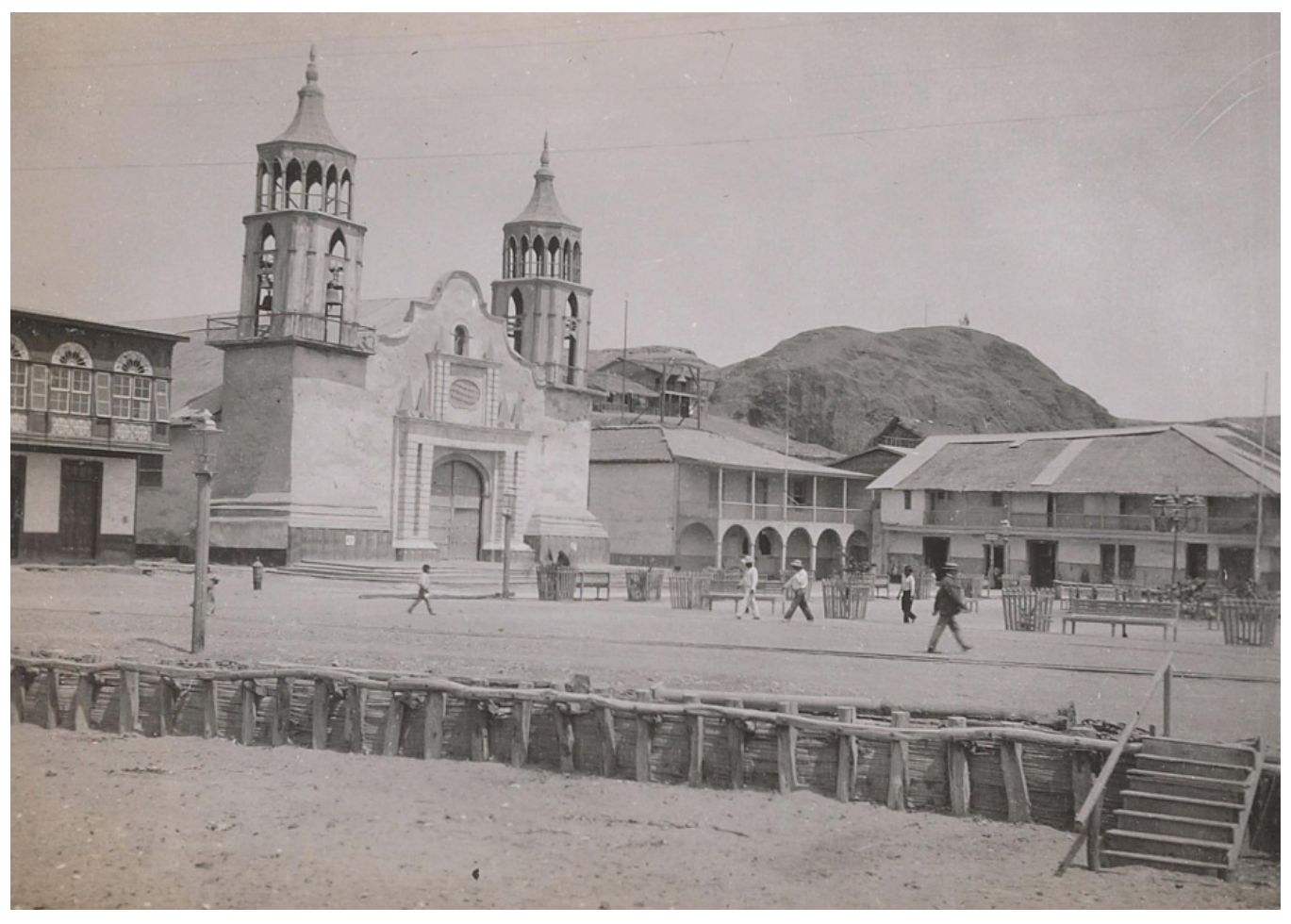

Fotografía de la iglesia y plaza central de Paita. Fuente: Shockley, William Hillman, 1855-1925. ([«Box 1 | Folder 6»]) (1903 May 11) [Photographs of Peru.]. https:// collections. library.yale.edu/ catalog/10507568. 
los Yngas, con tambos, puentes y pequeños poblados de pescadores, agricultores y ganaderos dispersos en las quebradas y tablazos, garantizando la comunicación entre Trujillo y los pueblos andinos de la Audiencia de Quito.

Durante estos años decisivos se instauraron y se pusieron en funcionamiento una variedad de instituciones ligadas al Estado y a la Iglesia, como nuevos símbolos de poder virreinal que habían desplazado a los gobernantes Yngas y al sistema del Tawantinsuyo desde finales de 1532. La guerra entre los Yngas y Carlos V había debilitado la estructura agropastoril y liquidado a las elites quechuas, también a los gobernantes tallanes y los guayacundos. En buena cuenta, las reformas políticas de Toledo invertirán la geografía poblacional, esta vez inclinada hacia el espacio yunga en donde estaban asentados grandes bloques poblacionales al servicio del nuevo poder virreinal (Espinoza Claudio, 2020; Diez, 1997:151-172).

Payta es un puerto que agiliza el movimiento del oro y la plata transportada por las rutas terrestres y marítimas; en los microvalles vecinos de CatacaosSechura y de Colán-Amotape se asegura el cultivo y la cosecha del maíz-trigo, del algodón y las verduras para asegurar la alimentación de los salientes e ingresantes al virreinato del Perú por esta ciudad-puerto en proceso de construcción.
Entre 1570 y 1580, la ciudad de San Miguel de Piura creció al pie de la cordillera, explotando las obras hidráulicas de los Yngas y las poblaciones multiétnicas, en las nacientes estancias y haciendas organizadas en toda la provincia y corregimiento de Piura. El FEN de 1578 generó una ruptura de la agricultura yunga y del sistema de crianza ganadera impulsada por las familias españolas que habían logrado asentarse en este microespacio rural. Las lluvias e inundaciones favorecieron una migración obligatoria de los encomenderos, los labradores de la tierra, y las elites indígenas, para estacionarse en las tierras de la comunidad indígena de Payta. La ciudad de San Miguel de Piura quedaría destruida y abandonada, y las tierras de la hacienda, más adelante denominada el sitio de "Monte de los Padres», permanecerá deshabitada, rodeada por los médanos y los bosques de algarrobo.

En Payta se organiza una nueva microurbe, agrupando a las familias de los españoles migrantes, instalándose las autoridades enviadas desde la ciudad de Lima, mientras se reanudan los contratos entre los comerciantes y labradores de la tierra provenientes de otros valles como Saña, Trujillo, Panamá y Lima. Este grupo de españoles bautizará a la nueva ciudad con el nombre de San Francisco de la Buena Esperanza, asentada en las orillas del mar y las tierras indígenas

\begin{tabular}{|l|l|}
\hline Nombres, apellidos y datos adicionales & \\
\hline Alonso Forero de Ureńa (corregidor) & Antonio de Frías \\
\hline Gaspar Troche de Buitrago (teniente) & Gonzalo Farfán \\
\hline Miguel de Salcedo & Gabriel de Miranda, alcalde \\
\hline Juan Franco Vaca & Juan de Quiroga, alcalde y contador \\
\hline Francisco Cornejo & Alonso Ruiz \\
\hline Diego Vaca de Sotomayor & Rodrigo Méndez \\
\hline Rui López Calderón & Juan Losada de Quiroga \\
\hline Pedro de Saavedra & Fray Gaspar Farías, Comendador de La Merced \\
\hline Dos frailes mercedarios & Fray Pedro Martínez \\
\hline Bartolomé García & Juan García de Escobar \\
\hline Juan de Castilla & Juan Alonso de Albújar \\
\hline Gonzalo Prieto Dávila & Antonio Suarez de Medina \\
\hline Juan de Torres & Bartolomé García \\
\hline Gaspar de Valladolid & Gonzalo Prieto \\
\hline Pedro de Saavedra & Lázaro Giraldes \\
\hline Gonzalo Ribas, lengua y piloto & Diego de Grajeda, alférez \\
\hline A. Rodríguez Peńa & \\
\hline
\end{tabular}




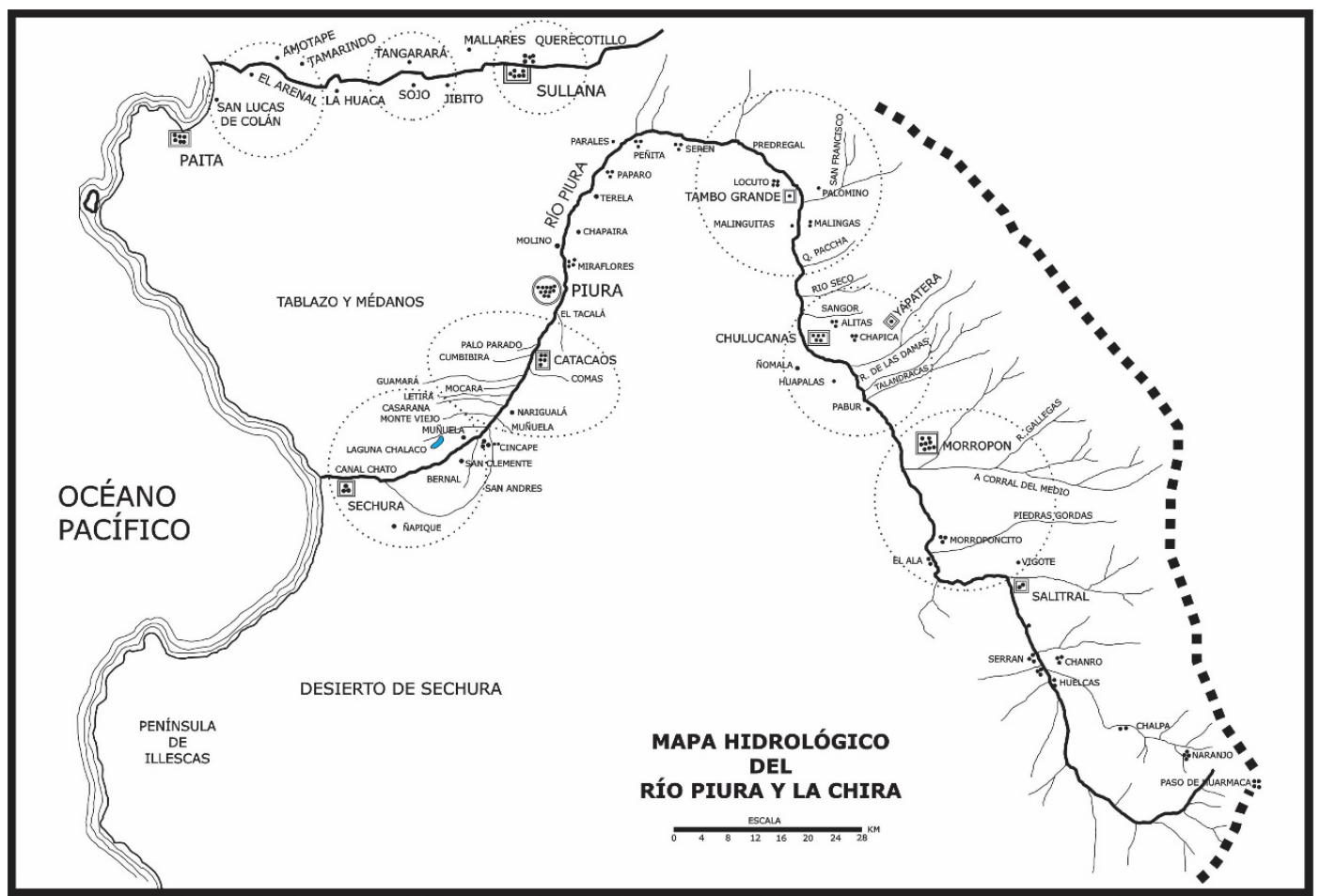

Fuente: Sistema de irrigación del río Piura a principios del siglo XX. En: Bernex, N. y Revesz, B. (1988). Atlass Regional de Piura (pag. 44). CIPCA-Piura. Digitalización del mapa: Pavel Espinoza, 2014 (Revisado en 2018).

de Payta. Se trata de una pequeña urbe que cumpliría temporalmente la función de bisagra comercial y de gobierno virreinal hasta 1587 , fecha en la que será invadida y destruida por el ejército y las naves conducidas por Thomas Cavendish, un marino y corsario ingles que navegó por todo el globo terrestre.

En efecto, para fortalecer la vida social en el corregimiento, el virrey estaba interesado en que funcionara en Piura un nuevo centro político localizado en un punto clave para el manejo de las corrientes y vientos marinos que facilitaran el movimiento de las embarcaciones reales y comerciales entre Panamá y Saña. De tal forma que, bajo el gobierno del virrey Conde del Villar, los grandes beneficiarios de esta nueva situación y ubicación residencial, luego de la destrucción de la ciudad de San Miguel de Piura en 1578 , son un grupo de familias españolas que figuran en el documento de 1587 que ahora publicamos (Ver el cuadro de texto: «Nombres, apellidos y datos adicionales»).

Ahora bien, recuperados los vecinos del trauma de la guerra provocado por Cavendish, empieza otro proceso, la fundación de una nueva urbe en el valle de Catacaos bajo el nombre específico de San Miguel de Piura del Villar en 1588. Concluido el ritual y la ceremonia de la toma de las tierras indígenas otorga- das por el rey de España, se organiza la designación de las autoridades y empieza a funcionar el Cabildo, realizando un nuevo reparto de tierras y la demarcación de lo que en adelante se llamaría los «Ejidos» de la ciudad.

El virrey Conde del Villar facilita y agita la bandera de la colonialidad del poder, fijando la presencia de la autoridad virreinal. El corregidor legitima el poder municipal, liderado por un grupo de familias espańolas que acceden a la tierra con la finalidad de aprovechar los trabajos de labranza, la formación de las estancias ganaderas, y el reinicio de sus tareas evangélicas por la Iglesia y los religiosos de la orden de la Merced.

España pone en funcionamiento tres grandes fuerzas institucionales: Estado, Cabildo, e Iglesia, para construir una cultura y un modo de vida hispana. Para ello, primero ejecutan la distribución, directa o indirecta, de las tierras de labranza y los campos de pastoreo en los valles de Tumbes, La Chira, Tambogrande, Morropón, Yapatera y Olmos. La ciudad está obligada a vivir de las rentas que ofrece el trabajo y la tierra; las familias de los hacendados y de los encomenderos se instalan a orillas del río, otros disfrutan de los repartos y aseguran cuotas del agua de los sistemas de riego que encuentran en las tierras 
comunales de Catacaos. De esta manera, se dispone un proceso temporal de continuidad con la labranza y la cosecha del algodón, maíz, trigo y otros productos de panllevar.

Un pequeño grupo de españoles buscaría controlar los médanos y los bosques de algarrobo para reproducir el ganado caprino, vacuno, porcino y mular, con la finalidad de reiniciar un proceso de acumulación de capital. En esta ciudad conviven españoles e indios cańares, pero también familias de negros esclavos con grupos de mitayos y yanaconas indígenas provenientes de la sierra y la yunga piurana. Conviven en proximidad física dentro de una pequeńa microurbe, pero separados por la cultura, las costumbres y la lengua de aquellos que representan a una república hispana excluyente como proyecto de vida de larga duración.

Por consiguiente, en un corto tiempo se conforman varios linajes y clanes familiares que patrimonializan sus bienes y rentas para el beneficio propio, disfrutan de cargos políticos y despliegan estrategias de parentesco para apoderarse de las tierras húmedas y los campos de pastoreo de ganado caprino y vacuno. La institución religiosa vivirá de las ganancias y rentas que le ofrecen los censos y las capellanías (Huertas, 1996:91-124). ${ }^{4}$

El Estado virreinal designa a las autoridades, esta vez es un corregidor el encargado de controlar la economía, las reglas y los estatutos de vida social del «sistema de la república de españoles». Se vigilará el funcionamiento de las encomiendas y la generación de sus rentas por los indígenas tributarios; pero también se impondrá la instrumentalización y la mediatización del sistema de las mitas. El mantenimiento del orden y el buen estado del patrimonio virreinal reciben supervisión. Las comunidades indígenas, sus caciques y cabildos están obligados a cumplir con la entrega anual de sus rentas, reproduciendo un sistema social jerárquico y la continuidad de las relaciones de parentesco al interior de sus parcialidades territoriales.

El Estado, el Cabildo y la Iglesia impondrán pautas y una variedad de comportamientos que se traducirán en la formación de una sociedad controlada por

4 Sobre la temática de las capellanías la literatura es abundante, yo he consultado a Gerardo Neira Zurita 2016; Gisela Von Wobeser 2005 y a Martínez López-Cano, María; Gisela Von Wobeser y Juan Muñoz Correa 1998. una mentalidad señorial y jerarquizada. El virreinato maneja una forma singular de representación del poder al interior de la sociedad yunga. En particular, busca refundar la sociedad indígena de Catacaos con la población yunga sobreviviente, para de allí reproducir y encargar el linaje yunga de La Chira a una familia tallán que había sobrevivido a la matanza masiva que había practicado Francisco Pizarro contra los señores étnicos asentados en un valle gobernado por una autoridad cuzqueña en 1532. Existió un especial interés en que se apoye la política colonial y se reproduzca una memoria histórica de resistencia pasiva, que llegaría incluso a bautizar el antiguo valle de Turicarami, con el nombre de La Chira, un espacio territorial ubicado entre Poechos y San Lucas de Colán.

Los sucesos de Payta en 1587 les servirán también a los gobernantes indígenas de Catacaos para afirmarse y negociar con las autoridades espańolas su propio espacio de poder laico y religioso, fortalecer el gobierno de sus parcialidades étnicas, y levantar el edificio de la Iglesia. En este caso, el cabildo de San Juan Bautista de Catacaos configura una ideología propia, valores y modo de vida, mientras despliegan prácticas y actitudes a favor del cristianismo, que los distinguirán del remanente de la sociedad regional. La edificación temprana de una iglesia en medio del desierto, el manejo de la represa de El Tacalá, la gestión de los caminos y tambos reales, el funcionamiento de una Caja Comunal, la formación de cofradías y el otorgamiento de préstamos de dinero en moneda plata, le permitirán a Catacaos reproducir la antigua estructura comunitaria tallán, sostenida por grandes y extensos campos cultivados de trigo, maíz y algodón, con una manufactura textil articulada al mercado y puerto de Payta. Sin embargo, nada detiene la vigilancia del bachiller Juan de Mori, un religioso benefactor, pero también comisario de la Santa Inquisición que labora con otros religiosos en la misión encomendada de extirpar las idolatrías yungas y las expresiones simbólicas del demonio en las huacas de Narigualá por ejemplo.

Así, se impondrá gradualmente un ideal de vida señorial, articulándose incluso bajo la forma de un ideal nobiliario en el gobierno de los caciques de todos los pueblos de la región de Piura. Varios estudios han confirmado el funcionamiento de este tipo de sociedad jerárquica que utilizará los principios de la 
organización comunal para generar excedentes tributarios y de subsistencia para los indígenas y los sectores sociales succionadores de la renta comunitaria. Los gobernadores indígenas, llamados caciques, están regulados por el sistema de la herencia y los sistemas de parentesco, pero también protegidos por la legislación indiana. La práctica social de la vida cotidiana relaciona los principios de convivencia social que van a impregnarse en las formas de asociación de los linajes y las parcialidades indígenas. La «república de indios» asocia a señores e indios, comunes y tributarios, jerarquizándolos con jefaturas y asignación de funciones políticas en el Cabildo de Indios, la Caja Comunal y el sistema de cofradías y de hermandades religiosas (Diez, 2006:107-127; Cruz Villegas, 1982:101-169).

En la provincia de Piura, los gobernantes indígenas asumirán como propios los comportamientos de la mentalidad nobiliaria. En el pueblo y su plaza central, el símbolo representativo es la Iglesia, una institución jerárquica que contribuyó a la diferenciación social y la desigualdad en el acceso a la tierra, mientras ocurrían prácticas sociales como el gozo del ocio aristocrático y la asimilación de comportamientos y valores caballerescos. Paralelamente, esta institución también favoreció el acceso a la escritura, a los rituales hispanos, promovió la residencia en solares y viviendas al estilo castellano, impulsó la adopción de la escritura de testamentos, la práctica de los funerales, y los servicios de las capillas funerarias con misas cantadas y festivas, legitimó el manejo de símbolos de poder como la vara y el duho para las alianzas matrimoniales con linaje indígena en los pueblos circunvecinos, promoviendo que al interior de la sociedad indígena se emplearan vestimentas singulares que expresen una particular visión del mundo y una idea de superioridad social. Todo viajero que desembarque por mar y cruce el desierto durante este tiempo, observará asombrado cómo los tañidos de las campanas en las torres marcan el movimiento del tiempo y el cumplimiento de tareas civiles o religiosas (Espinoza Claudio, 1999).

Los cacicazgos indígenas se institucionalizarán y se vincularán a la esfera religiosa y militar. Se construye todo un sistema de representaciones, imágenes y conceptos como instrumentos de dominación y reproducción de intereses nobiliarios con legitimación sociopolítica para ejercer su poder local y provincial.
Practican en su vida cotidiana una variedad de mecanismos de representación como la escritura y el arte para aportarle sostenibilidad en el tiempo. La mentalidad social será construida, impuesta y representada en la vida religiosa, fiscal y de gobierno a nivel local. Los encomenderos y las autoridades de la ciudad de San Francisco de la Buena Esperanza encuentran que esta gente de las diversas parcialidades yungas de Catacaos puede garantizarles el mantenimiento de sus vidas y familias, pero saben también que las leyes no les permitirán permanecer por mucho tiempo después del ataque destructivo por Cavendish en 1587.

\section{El mundo social de los caciques, su mentalidad y prácticas culturales señoriales}

Es probable que durante el gobierno del virrey don Francisco de Toledo se haya recreado este pueblo indígena de Catacaos, cuyos caminos circundantes confluyen en un tambo del mismo nombre. La información más temprana señala que al interior de este espacio, ocupando diversos microterritorios, confluyeron una variedad de parcialidades indígenas procedentes de otros lugares geográficos. No conocemos todavía como estos grupos enfrentaron el impacto del FEN de 1578, pero lo que sí se sabe es que los ayllus replicaron el principio de la dispersión para la ocupación social de la tierra entre Nariguala y Guamará, y dicha frontera agraria se expandió con el cultivo del trigo, maíz y algodón para el comercio fuera de las fronteras comunitarias.

A través de este corto intervalo temporal, el sistema social virreinal impondrá la reproducción de un tipo de comportamiento señorial entre la vida y la muerte de los miembros de su linaje. El trabajo de la tierra estará acompañado de rituales festivos que permitan gozar de momentos de ocio al estilo señorial, desarrollando el uso de sus bienes materiales para la construcción de una Iglesia, el manejo cíclico de la tierra, la celebración de los contratos, el establecimiento de negocios mercantiles, e incluso la práctica de la reciprocidad social para llegar a comprar y manejar negros esclavos como símbolo de su estatus social.

Los caciques yungas tendrán acceso a la escritura y a los libros, liderarán las fiestas de las cofradías, y buscarán controlar a los miembros del Cabildo de 
Indios. En general, las familias de estos linajes sociales son bilingües y vivirán ocupando sitios claves en las microurbes yungas como Catacaos, Colán, Sechura, Amotape y la propia ciudad de San Miguel de Piura (Elías, 2004, 2008).

Los lazos sociales que articulan la vida de individuos procedentes de varios grupos étnicos estarán dominados por los valores señoriales, pues sus elites buscarían ocupar lugares privilegiados cotidianos, como el acceso a una buena ubicación en las sesiones de las misas dominicales, reproduciendo incluso valores caballerescos como el portar armas y montar caballos y yeguas para desplazarse, vestir ropas de tela cumbe y participar de los rituales religiosos para los entierros con mortajas franciscanas o mercedarias.

Para el siglo XVII, la mayoría de los caciques conformarán una parte de la casta de los mestizos, cuyas vidas cotidianas estarán marcadamente concentradas en el seguimiento y la latención de los procesos judiciales para normalizar y garantizar la continuidad de su base material, representada por el manejo de fanegadas y varas de tierras comunales, el proseguir prolongados autos judiciales, y presentar apelaciones contra los encomenderos, corregidores y hacendados que alquilan sus tierras comunitarias, de las cuales pretenderían apoderarse.

La lucha por la tierra se desarrolla al interior de las facciones familiares, las cuales también se enfrentan a los grandes propietarios de tierras entre Congorá, Huamará y Letirá, territorios vecinos al tablazo desértico de Payta y Olmos, e incluso hasta Pariñas y Tumbes.

En esta oportunidad, los gobernantes yungas pugnaran por monopolizar el poder cacical, la posesión y el manejo de las tierras húmedas y los extensos bosques de algarrobo y zapote existentes entre la orilla del mar y el piedemonte cordillerano de Morropón, Tambogrande y Yapatera. El acceso a la tierra agrícola y a los contratos mercantiles agrarios provocará mucha tensión, hasta la prolongación y desplazamiento del sistema de los corregidores y su reemplazo por los subdelegados en el siglo XVIII. En este tiempo histórico, los caciques de sangre han sido desplazados por los caciques mestizos portadores de títulos nobiliarios comprados y reconocidos por el virrey. En el transcurso del último tercio de este siglo crecerá su alianza con la Iglesia y los representantes de las órdenes religiosas. Sin embargo, los Borbones los desplazarán en el mando, para después encargarles la autoridad a los alcaldes y regidores del Cabildo de Indios y sus parcialidades (Diez, 2017; Espinoza Claudio, 2020).

Durante el siglo XVIII, muchos de los caciques son educados en Trujillo y Lima; sus vidas estarán articuladas a los mandatos de los curas y vicarios, pero también a los religiosos de la orden de San Francisco, La Merced y los Betlemitas. La iglesia les obligará a aprender el idioma castellano y la gramática en latín, conocimientos usados en Lima, preservando su lengua original y reafirmando la doctrina cristiana. Por otro lado, en la Caja de la Real Hacienda se captan y acumulan los tributos, la alcabala, los impuestos de avería y los almojarifazgos.

\section{El mundo indígena, el sistema de poder y el juego de los símbolos en un territorio desértico}

Una variedad de sucesos laicos y religiosos les permitirán a los gobernantes indígenas a expresar públicamente los símbolos propios de su nobleza. La presencia de corsarios o piratas ingleses, la muerte de un rey o una reina, la llegada de un nuevo virrey, o incluso la muerte de un curaca, son momentos importantes para simbolizar y reafirmar su estatus social, tanto al interior de la sociedad indígena como frente a la sociedad española. Esta vez los marcos legales se objetivan, dando forma y funcionalidad a la «república de indios", cuyas dinámicas previamente se mantenían ocultas y misteriosas. En consecuencia, se manifiestan con fuerza la permanencia de los apellidos y linajes familiares, los escudos y símbolos, las reales cédulas o decretos de fidelidad al rey de España, la subordinación de los miembros de cabildo, y la asistencia colectiva a las misas. Estas y otras acciones sociales posibilitarán remarcar la condición de noble e interiorizar una organización de la sociedad en ayllus y parcialidades.

Los eventos sociales que se realizan en el pueblo y otros microespacios territoriales les permitirán exhibir una variedad de símbolos, especialmente durante fechas y acontecimientos especiales como son los entierros, las fiestas o las movilizaciones militares. Un conjunto de expresiones simbólicas se registra con la movilización de los integrantes del Cabildo y las parcialidades, los representantes de las cofradías, y las comitivas movilizadas hacia el puerto de Payta o la ciudad de San Miguel de Piura para participar de los 
programas organizados por los corregidores o alcaldes ordinarios. Se trata de momentos históricos cruciales para hacer público su poder sobre la sociedad indígena y sus vinculaciones señoriales con el poder virreinal en su calidad de súbditos y vasallos de la corona hispana. Estas expresiones se manifiestan al interior de un espacio regional, y es aquí donde la dimensión social se expresa en la formación y funcionamiento de los estamentos marcados racialmente, poseedores de memorias históricas diferenciadas, pero compartiendo la cultura dominante, regida por una legislación e instituciones que le dan sentido y significado coyuntural, para afirmar así el sistema de la colonialidad del poder hispano disperso en microsociedades como Narigualá, La Chira o Simbilá.

En la comunidad de SJB de Catacaos, el territorio manejado por la nobleza y las parcialidades yungas empezará a diferenciarse, por su crecimiento poblacional y vinculación a un mercado interno ligado a la demanda comercial del puerto de Payta. El tráfico marítimo virreinal para las exportaciones e importaciones obligará a las familias yungas a expandir sus sistemas parcelarios agrícolas a lo largo del río Piura, explotando las zonas húmedas y de jagueyes que les permitirán cultivar trigo, maíz y algodón. La llegada anual de las descargas de agua modificará temporalmente las fronteras de las parcelas yungas, mientras que los cercos y los bosques que marcan las fronteras de los espacios comunales administrados por los dirigentes y las familias yungas en sitios extensos como Letírá y Guamará, cruzados por caminos y puentes de palos de zapote y algarrobo, se prolongarán por los médanos desérticos y llegarán hasta Congorá, un punto cercano al puerto de Payta.

En el siglo XVIII se afirmará la microurbe de Catacaos con la reconstrucción de la Iglesia, los depósitos comunales, las viviendas y solares de las familias indígenas más ricas, y la conformación de un pequeño grupo de comerciantes mestizos y de españoles que vivirán del arriendo de las tierras de Yupita, Simbilá, Narigualá y Chocholla, administrando una red de acequias y canales que cruzaran temporalmente estos espacios de labranza y de concentración de animales de cerda y ganado caprino, vacuno y mular (Cruz Villegas, 1982: 129-169).

La plaza central empieza a organizarse con pequeñas calles y solares circunvecinos a la Iglesia, en donde varias facciones nobiliarias, desde este punto, y apoyados por los encomenderos y corregidores, practican el ejercicio de control de la jurisdicción señorial indígena cataquense. La masa indígena, que trabaja la tierra y explota los extensos pastizales comunales, empezará a tomar posesión de estos territorios, instalando sus cabañas y chozas, cercándolas con palos y carrizos para delimitar sus parcelas de orilla trabajadas temporalmente, pero con posesiones familiares de naturaleza permanente. Los grupos de familiares realizarán la toma de posesión de estos microespacios bajo la vigilancia de las autoridades municipales indígenas y el consentimiento de los caciques yungas. De otra parte, al interior de las parcialidades también se encuentra una diferenciación entre los llamados indios "comunes", otros indios que forman parte de una pequeña nobleza, y los «indios forasteros», expresando así el funcionamiento dinámico de una estructura con diferentes jerarquías sociales indígenas.

De tal suerte que al interior de la sociedad cataquense se desplegará un simbólico mapa de clanes familiares diferenciados entre grupos sociales asentados en Narigualá o Guamará, los cuales pese a estar ubicados en espacios territoriales discontinuos recibirán una vigilancia de sus movimientos económicos y dinámicas rituales por parte de los caciques gobernantes y los comisarios de la Santa Inquisición. Queda como tarea pendiente estudiar los libros de bautismos, matrimonios y entierros para introducirnos al examen de los sistemas parentales, para conocer con más detalle y profundidad este proceso de identidad y diferenciación que utilizan las familias, que fueron registrando sus apellidos de manera reiterada o dispar, durante periodos de tiempos cortos y largos, para así verificar la intensidad de sus interrelaciones y lazos sociales.

Los estudios realizados por Oswaldo Fernández (1988, 1998), Eduardo Franco (1981) y Jorge Elías (2004) nos permiten disponer de un conjunto de evidencias documentales sobre la cultura cataquense. En particular, conocer la representación de una mentalidad nobiliaria y sus símbolos, usados por los caciques, las autoridades del Cabildo de Indios y los gobernantes de las parcialidades indígenas. El uso de las varas, los duhos, las joyas hechas en oro y plata, las vestimentas de tela cumbe, el algodón nativo de diversos colores, junto a los pendones, estandartes y cruces en las actuaciones religiosas, constituyen representaciones y señales culturales que denotan la preeminencia de su status social, de valores asociados 
como el honor y la dignidad para la formación de identidades indígenas en Catacaos. La importancia de lo simbólico destaca en la vida cotidiana de hombres y mujeres, trazando la apariencia de sus cuerpos, sus viviendas y calles, sus interacciones con las autoridades criollas y españolas, para reafirmar la existencia y legitimidad de sus privilegios, cargos y sanciones reconocidas por el virrey del Perú y los reyes de España. Poderes y privilegios, cargos y símbolos, favorecerán la continuidad del sistema de curacazgos hasta su liquidación a finales del siglo XVIII, por efecto de la represión política contra el mundo andino y Tupac Amaru por los Borbones reales.

Con la afirmación territorial de este micropueblo rural de Catacaos se expandirá el poder de la familia La Chira, por ejemplo. Cada grupo familiar portará insignias probatorias de su fidelidad real; para la dimensión de la muerte, sus sepulcros estarán materialmente ubicados en capillas y actuaciones funerarias cercanas al local de la Iglesia en Catacaos. Asimismo, en los alrededores de la pequeña plaza, los indios y mestizos ricos empiezan a construir sus viviendas y moradas al estilo de las mansiones existentes en la ciudad de SM de Piura. Por tanto, mediante estas obras arquitectónicas de adobe, paja y piedra, este pequeño grupo social utilizará a los maestros albañiles para levantar nuevas casas y calles, y así exhibir su poder económico, político y cultural. En esta ocasión, aparecen nuevos linajes en la microurbe, dedicados inicialmente al comercio con Payta y Sańa, para luego extender sus actividades hacia Trujillo y Lima. Para el caso de la iglesia de Catacaos, debido a los efectos del FEN y los terremotos, se priorizará su reconstrucción y mantenimiento, pero esta vez buscando representar a santos y santas, acompañados de novedosas liturgias, procesiones y una notable profusión de música y fuegos artificiales.

\section{Referencias bibliográficas}

Betanzos, Juan de (1551) (1987). Suma y narración de los incas. Madrid, Atlas, España.

Busto Duthurburu, José Antonio del (2017). Túpac Yupanqui el resplandeciente. Tomo I. El conquistador. Tomo II. El gobernante. Piura: Universidad de Piura.
Busto Duthurburu, José Antonio del (1969). Dos personajes de la conquista del Perú. Lima: Editorial Universitaria.

Camino, Lupe (1982). Los que vencieron al tiempo: Simbilá, Costa Norte, perfil etnográfico de un centro alfarero. Piura: CIPCA.

Castañeda Murga, Juan (1996) Notas para una Historia de la Ciudad de Trujillo del Perú en el Siglo XVII. En: Tomoeda, H., y Millones, L. (1996). La tradición andina en tiempos modernos (pp. 159-189). Osaka: National Museum of Ethnology.

Castañeda Murga, Juan (2016). Génesis y colapso de una ciudad indiana del norte peruano. Santiago de Miraflores de Sańa, 1563-1720. En: Calvo, L. M., y Cocco, G. (coord.) (2016). Primeros asentamientos españoles y portugueses en la América central y meridional: siglos XVI y XVII (pp. 51-62). Santa Fe: Universidad Nacional del Litoral.

Cornejo, Raúl Estuardo (2007). El Alma de Piura. Elogio a un sentimiento. Lima: Editorial San Marcos.

Cortez González, Shirley (2018). Léxico del español de la zona norte peruana en testamentos de los siglos XVI y XVII. En: Arnal Purroy, María Luisa et al. (coord.) (2018). Actas del X Congreso Internacional de Historia de la Lengua Española: Zaragoza, 7-11 de septiembre de 2015 (vol. 2, pp. 1887-1902). Zaragoza: Institución Fernando el Católico. https://dialnet.unirioja.es/ servlet/articulo? codigo $=6935829$

Costa Vigo, Luis (2017). Por no yr tan solo. Redes clientelares y dinámicas de poder en el virreinato del Perú: el caso del gobierno del virrey conde del Villar, 15851590. En: Suárez, M. (2017). Parientes, criados y allegados: los vinculos personales en el mundo virreinal peruano (pp.37-67). Lima: Pontificia Universidad Católica del Perú (PUCP)/ Instituto Riva-Agüero (IRA).

Costa Vigo, Luis (2016). ¿Prácticas corruptas o relaciones de patronazgo? Orden patrimonial y la naturaleza del sistema político en el Perú durante el gobierno del virrey conde del Villar (1585-1590). En: Rosenmüller, C. y Ruderer, S. (2016). "Dádivas, dones y dineros»: aportes a una nueva historia de la corrupción en América Latina desde el imperio español a la modernidad (pp. 2760). Madrid: Iberoamericana; Frankfurt: Vervuert.

Cruz Villegas, Jacobo (1982). Catac-Ccaos: Origen y evolución histórica de Catacaos. Piura: CIPCA.

Diez Hurtado, Alejandro (1997). Caciques, cofradías, memoria y parcialidades. Un ensayo sobre el origen de la identidad cataquense. Anthropologica, 15(15), 151- 
172. Recuperado a partir de https://revistas.pucp.edu. pe/index.php/anthropologica/article/view/1210

Diez Hurtado, Alejandro (2006). Los problemas del poder: política local y gobierno en las reducciones de la costa de Piura, siglo XVII. Anthropologica, 24(24), 107-127. Recuperado a partir de https://revistas.pucp. edu.pe/index.php/anthropologica/article/view/2090

Diez Hurtado, Alejandro (2017). Propiedad y territorio como (diferentes) bienes comunes. El caso de las tierras de comunidades en la costa norte peruana. Eutopia, Revista De Desarrollo Económico Territorial (11), 17-39. https://doi.org/10.17141/eutopia.11.2017.2851

Echeandía, Juan y Wisbar, Renate (1990). Los ceramistas de Piura. Lima: Seminario de Historia Rural Andina, Universidad Nacional Mayor de San Marcos (UNMSM).

Edson, Paulo (2020). Thomas Cavendish: O Corsário de Ilhabela. O manuscrito do corsário Thomas Cavendish que em 1591 se refugiou em Ilhabela e squeou a vila de Santos. Edición Kindle. https://www.amazon.com/-/ es/Paulo-Edson/dp/B08CPJJTRD

Elías Lequernaqué, Jorge Pável (2004). Los señores resisten: los caciques de Catacaos y sus estrategias de actuación $y$ adaptación en la sociedad piurana del siglo XVII. [Tesis de Maestría en Estudios de la Cultura, Universidad Andina Simón Bolívar]. Repositorio institucional de la Universidad Andina Simón Bolívar https://repositorio. uasb.edu.ec/handle/10644/2713

Elías Lequernaqué, Jorge Pável (2008). Don Sebastián de Colán y Parińa y sus ancestros: caciques de dos pueblos de la costa del corregimiento de Piura (s. XVI-XVII). Bulletin de l'Institut Français d'Études Andines, 37(1), 151-161.

Escandell Bonet, Bartolomé (1950). Aportación al estudio del gobierno del conde de Villar: hechos y personajes de la corte virreinal. Revista de Indias, 10(39), 69-95.

Espinoza Claudio, César (1999). Sociedad indigena, tierra y curacazgos yungas en la región de Piura, siglos XVI-XVII. Catacaos y los desafios de la naturaleza, 1532-1732. [Tesis de Maestría en Historia, PUCP]. Repositorio institucional de la Pontificia Universidad Católica del Perú https://tesis.pucp.edu.pe/repositorio/ handle/20.500.12404/7227

Espinoza Claudio, César (2020). La formación del sistema agrario colonial en Piura. Anotaciones sobre la ciudad de San Miguel y el nacimiento de la hacienda Tangarará, siglos XVI-XVII. Investigaciones
Sociales, (44), 259-291. https://doi.org/10.15381/ is.v0i44.19572

Espinoza Soriano, Waldemar (2006). La Etnia Guayacundo en Ayabaca, Huancabamba y Caxas (Siglos $X V-X V I)$. Lima: Fondo Editorial Pedagógico San Marcos.

Fernández Villegas, Oswaldo (1988). Curacazgos de la costa norte: Piura. Boletín de Lima, (60), 45-47.

Fernández Villegas, Oswaldo (1998). Conflictos por el poder en Colán, siglos XVII-XVIII. Piura: Cámara de Comercio y Producción de Piura.

Figueroa, Guillermo y VÁsquez, Iris (2020). Dos procesos olvidados: la catástrofe demográfica y la imposición de «reducciones de indios» en el norte peruano. Investigaciones Sociales, 23(43), 239-248. https://doi. org/10.15381/is.v23i43.18496

Franco Temple, Eduardo (1981). Grupo cataquense y ritual en la fiesta de Semana Santa. [Tesis de Bachiller, PUCP].

Glave, Luis Miguel (1991). El puerto de Paita y la costa norteña en la historia regional de Piura. Bulletin de l'Institut Français d'Études Andines, 20(2), 501-509. http://www.ifea.org.pe/libreria/bulletin/1991/

Glave, Luis Miguel (1993). La Puerta del Perú: Paita y el extremo norte costeńo, 1600-1615. Bulletin de l'Institut Français d'Études Andines, 22(2), 497-519. http://www.ifea.org.pe/libreria/bulletin/1993/

HaKLUYT, Richard (2015). The prosperous voyage of worshipful Thomas Cavendish of Trimley in the County of Suffolk Esquire, into the South Sea, and from thence round about the circumference of the whole earth, begun in the year of our Lord 1586, and finished 1588. En: Hakluyt, Richard (2015). The voyage of Sir Francis Drake around the whole globe. Londres: Penguin Classics.

Hampe, Teodoro (2002). Un capítulo de historia regional peruana: la ciudad de Zańa y su entorno ante la inundación (1720). Revista Andina, (34), 65-83. http:// revista.cbc.org.pe/index.php/revista-andina/article/ view/587

Hampe, Teodoro (1986). El tesorero Alonso Riquelme y la administración financiera en la conquista del Perú (1531-1548). Histórica, 10(1), 45-87. https://revistas. pucp.edu.pe/index.php/historica/article/view/8231

Hocquenghem, Anne-Marie (1990). Los Guayacundos de Caxas y la sierra piurana, siglos XV $X V I$. Piura: CIPCA; Lima: IFEA. https://books.openedition.org/ifea/1100 
Hocquenghem, Anne-Marie (1994). Los españoles en los caminos del extremo norte del Perú en 1532. Bulletin de l'Institut Français d'Études Andines, 23(1), 1-67. http://www.ifea.org.pe/libreria/bulletin/1994/

Huertas, Lorenzo (1987). Ecología e Historia. Probanzas de indios y españoles referentes a las lluvias de 1578 en los corregimientos de Trujillo y Saña. Chiclayo: Centro de Estudios Solidaridad.

Huertas, Lorenzo (1993). Fundación de la villa de Santiago de Miraflores de Zaña: Un modelo hispano de planificación urbana. Historia y Cultura, (22), 145-204.

Huertas, Lorenzo (1991). Perturbaciones étnicas en Piura. Bulletin de l'Institut Français d'Études Andines, 20(2), 489-500. http://www.ifea.org.pe/libreria/ bulletin/1991/

Huertas, Lorenzo (1996). Patrones de asentamiento poblacional en Piura (1532-1850). Bulletin de l'Institut Français d'Études Andines, 25(1), 91-124. http://www. ifea.org.pe/libreria/bulletin/1996/

Huertas, Lorenzo (1997). Cronología y tipología de los centros poblados de la región de Piura. En: Varón, G. y Flores, G. (1997). Arqueología, antropología e historia en los Andes: Homenaje a María Rostworowski (pp. 471-486). Lima: Instituto de estudios peruanos (IEP), Banco central de reserva del Perú (BCRP).

Jaramillo Arango, Antonio (2019). Navegación indígena en el puerto de Paita. Abasto y contrabando. Bulletin de l'Institut Français d'Études Andines, 48(1), 39-55. https://doi.org/10.4000/bifea.10397

Johnstone, Christian Isobel (1900). Lives and voyages of Drake, Cavendish, and Dampier; including an introductory view of the Earlier discoveries in the South Sea and the History of the bucaniers. New York: A. L. Fowle. https://library.si.edu/digital-library/book/ livesvoyagesofd00john

Knivet, A. (2007). As incriveis aventuras e estranhos infortunios de Anthony Knivet: Memórias de um aventureiro inglês que em 1591 saiu de seu país com o pirata Thomas Cavendish e foi abandonado no Brasil, entre indios canibais e colonos selvagens. Rio de Janeiro: Jorge Zahar.

Levillier, Roberto (1925). Gobernantes del Perú. Cartas y Papeles. Siglo XVI, El Conde del Villar (1548-1587) (Tomo X). Madrid: Imprenta de Juan Pueyo. https:// archive.org/details/gobernantesdelpe10peru

Lohmann Villena, Guillermo (1979). Personajes y estampas de Piura virreinal. Piura: Universidad de Piura.
Maticorena Estrada, Miguel (1999). La Fundación y el nombre de San Miguel, Piura, 1532. Piura: Época 313, pp.26-28, Perú.

Maticorena Estrada, Miguel (2001). Proyectos de irrigación en Piura. En: Universidad Nacional de Ingeniería (UNI), Proyecto Historia UNI (2001). Construyendo el Perú II. Aportes de ingenieros y arquitectos. Actas del II Congreso de Historia de la Ingeniería y la Arquitectura en el Perú (pp. 15-32). Lima: UNI.

Martos, Néstor (1958). De Tangarará al Chilcal: fundaciones y traslados de la ciudad de San Miguel de Piura. En: León Saldívar, Rómulo (comp.) (1958). Prosistas piuranos (pp. 158-166). Lima: Imprenta Minerva.

Martínez, María; Von Wobeser, Gisela; y Muñoz, Juan (Coord.) (1998). Cofradías, capellanias y obras pias en la América Colonial. México: Universidad Nacional Autónoma de México, Instituto de Investigaciones Históricas. https://www.historicas.unam.mx/ publicaciones $/$ catalogo/ficha?id $=344$

Mira Caballos, Esteban (2018). Francisco Pizarro. Una nueva visión de la conquista del Perú. Barcelona: Crítica.

Moya Espinosa, Reynaldo (1994). Historia de Payta. Panorama Editores: Municipalidad Provincial de Paita.

Neira Zurita, Gerardo (2016). Las capellanías en Piura 1780-1820. Trujillo: Universidad Nacional de Trujillo, Facultad de Ciencias Sociales, EAP de Historia.

Paz Velásquez, Juan (1986). Piura en la conquista. Piura: Industria Gráfica Ubillús.

Ramírez, Susan (1991). Patriarcas provinciales, La tenencia de la tierra en el Perú colonial. Madrid: Alianza Editorial.

Ramírez, Susan (2008) Trazos del pasado: La época colonial en La Libertad. Trujillo: Minera Aurífera Retamas S.A. (MARSA).

Romero, Carlos (1925). Prólogo. En: Levillier, Roberto (1925). Gobernantes del Perú. Cartas y Papeles. Siglo XVI, El Conde del Villar (1548-1587) (Tomo X, pp. V-XXI). Madrid: Imprenta de Juan Pueyo. https://archive.org/details/gobernantesdelpe10peru

Schlüpmann, Jakob (1991). Structure agraire et formation d'un ordre social au nord du Pérou : Piura à l'époque coloniale. Bulletin de l'Institut Français d'Études Andines, 20(2), 461-488. http://www.ifea.org.pe/libreria/bulletin/1991/pdf/461.pdf

Seiner Lizárraga, Lizardo (2017). Historia de los sismos en el Perú. Catálogo: siglos XV-XVII. Lima: Universidad de Lima. https://repositorio.ulima.edu. pe/handle/20.500.12724/10796 
Vega, Juan José (1993). Pizarro en Piura. Piura: CYDES, Concejo Provincial de Piura.

Wachtel, Nathan (1976). Los vencidos. Los indios del Perú frente a la conquista española (1530-1570). Madrid: Alianza Editorial.

Wobeser, Gisela von (2005). Vida eterna y preocupaciones terrenales: las capellanias de misas en la Nueva España 1600-1821. México: UNAM, Instituto de Investigaciones Históricas.
ZeVAllos Quiñones, Jorge (1996). Los fundadores y primeros pobladores de Trujillo del Perú. Trujillo: Fundación Alfredo Pinillos Goicochea.

Zevallos QuiÑones, Jorge (1985). Semblanza histórica de la ciudad de Trujillo durante el Virreynato (1534-1820). Lima: Banco Central de Reserva del Perú. 


\section{Anexo documental. Captura, saqueo e incendio del puerto de Payta, 1587}

«En el pueblo de San Juan del valle de Catacaos en términos e jurisdicción de la ciudad de San Francisco de Buena Esperanza del puerto de Payta en treinta días del mes de septiembre e 1587 años. El capitán Alonso Forero de Ureña, corregidor de la ciudad y su jurisdicción por el rey nuestro señor». ${ }^{5}$

Por ante mí Miguel de Salcedo, escribano nombrado dijo que por cuanto él es venido de la ciudad de los reyes a donde a estado y estuvo un año poco más o menos en ciertos pleitos y demandas que se le pusieron y por virtud de una provisión mandada de la Real Audiencia de los Reyes en que se le mandó salir del distrito de su corregimiento e no volviera a él sin su licencia y con licencia del Conde del Villar visorrey destos reinos, y estando en la dicha ciudad detenido y volviendo por su justicia, entraron en esta Mar del Sur los ingleses, corsarios y vinieron las nuevas de su llegada de Chile y por esta costa del Perú hasta que un sábado 29 día del mes de mayo de este presente año de 87 entraron en el puerto de Payta y saltaron en tierra y la quemaron y arruinaron por ser cubiertas de paja y haberla desamparado los vecinos y demás personas que en ella estaban y retirándose a los altos del tablazo dejando las casas solas, porque por orden del dicho visovirrey tenían las mujeres y la demás hacienda en este pueblo de Catacaos y en otras partes retirado, atento a la poca gente y fuerza de la dicha ciudad y la orden que tenía Gaspar Troche de Buitrago, teniente que dejó en su lugar por su ausencia y por haber hecho la fuga y desamparo las casas y no haber tenido advertencia a recoger toda la gente de distrito como era obligado el dicho teniente, y asimismo por no haberle tenido otra gente que allí desembarcaron de la que venía de Tierra Firme y por haberse retirado con los dichos vecinos y haberse quemado los papeles e registros antiguos e modernos de la ciudad y para que conste la orden que el dicho teniente tomó del dicho visorrey y si la guardó y cumplió y paresca los culpados y revelase en venir en su mandado y socorro de la dicha ciudad y la culpa de los que estuvieron presentes en no obedecer y de quererse venir como se vinieron a este pueblo

5 Archivo General de Indias, Patronato 191, R. 7, Payta. Probanza sobre la quema de Payta, 1587. de Catacaos por el deseo que tenían de poblarse en el y despoblar la dicha ciudad de Payta por no tener casa en ella ni habella querido edificar, y para averiguar asimismo las culpas y descuido del dicho Gaspar Troche de Buitrago su teniente mandó hacer e hizo la cabeza de proceso siguiente, para que conste a S.M de todo ello y de la ausencia del dicho corregidor y de la gente que hubo y quienes eran y los testigos que juraren y depusieren sea por esta cabeza de proceso y así lo proveyó e mandó e firmó de su nombre Alonso Forero, ante mi Miguel de Salcedo, escribano nombrado (f.2).

Yt. en el pueblo de lo susodicho en este dicho día, mes y año susodicho el dicho corregidor Alonso Forero Ureña para la dicha información como e recibido juramento en forma de derecho de Juan Franco Vaca, estante al presente en este dicho pueblo del cual el dicho corregidor como e recibido juramento en forma de derecho e lo hizo cumplidamente e siendo preguntado al tenor de la dicha cabeza de proceso dijo que este testigo estuvo en la dicha ciudad de Payta al tiempo que el inglés entró en el puerto y salió en el antes que viniera estaba en este pueblo de Catacaos y antes que viniese la nueva está en el distrito por mandado de Gaspar Troche de Buitrago, teniente de corregidor que tenía a cargo la dicha ciudad por la ausencia del dicho capitán Alonso Forero corregidor que fue de este pueblo a la ciudad de Payta a hallarse allí con los demás soldados con sus armas para la defensa della y estuvo ocho meses poco más o menos en ella, y en este tiempo llegó el inglés corsario y entró en el puerto de Payta a donde tenían hecho un fuertesuelo de madera junto a la mar y casas reales de Aduana donde se recogieron todos los soldados y vecinos que serían por todos como 45 personas poco mas o menos, entre las cuales había diez vecinos y entre los cuales estaban cuatro viejos de mucha edad y los dos de ellos ansí por la edad, como por ser enfermos, estaba el uno de ellos que es Francisco Cornejo en este pueblo y con la ropa en lo alto del tablazo, Diego Vaca y asimismo vio alguna gente de los soldados (f.2) bisoña y era poca en que había seis o siete mestizos y tres o cuatro mulatos y otros mozos de ganado y gente de poca experiencia y, con todo estuvieron en el dicho fuerte con hasta 25 arcabuces y 
poca munición porque nunca vino de Lima ninguna munición ni se envió ni hubo más de una botija de pólvora que se repartió en dos o tres veces, y falto de plomo, y ansí estuvieron aquella tarde que se descubrió el inglés que fue viernes 28 de mayo y aquella propia noche surgió el inglés con tres navíos y una lancha que traía y velo este testigo y los demás soldados toda la noche guardando el orden que se le dio por el teniente capitán que era don Gaspar Troche de Buitrago y que estuvieron con buen ánimo y enteros aquella noche, con mucha vigilancia, guardando la playa hasta el sábado siguiente que amaneció sin que el inglés saltase en tierra y al fin al amanecer recogió la gente de todos los navíos y los echó en la lancha y en un batel y fue arrimando los navíos a tierra y arbolando las banderas, haciendo señal de guerra, y a todo esto estaban con muy buen ánimo por el aviso que tenían de ser pocos los ingleses que no eran más de 100 hombres, y luego comenzaron a tirar artillería y tirar al fuerte y tiraron dos piezas que dieron el dicho fuerte,

y luego incontinente vio este testigo venir la lancha hacia tierra con hasta 40 hombres poco más o menos y el batel cargado de gente que en efecto serían todos 90 e tantos hombres y visto la mucha fuerza de gente y que era gente de guerra y la ventaja reconocida, por orden del dicho teniente y parecer de algunos vecinos y gente que allí estaba se retiraron con su estandarte, la que está arriba a dar a lo alto del tablazo con buena orden y subieron a lo alto a donde tenían acordado por algunas gentes y el dicho teniente de hacerse fuertes,

y en llegando a lo alto vio este testigo que el inglés echó la gente en tierra y cuando fueron los postreros arriba que fue este testigo y Rui López Calderón (f. $2 \mathrm{v}$ ), este testigo fue a subir a su caballo y entonces pasaron los que quedaban atrás que fueron el dicho Rui López Calderón, Gonzalo Farfán y Antonio de Frias, Rodrigo Mendez, Gabriel de Miranda, Juan de Quiroga y Alonso Ruiz, y los ingleses iban en su seguimiento dándoles caza con su arcabucería tanto que iban casi juntos con ellos y en llegando a donde tiene dicho vio este testigo que faltaba mucha gente y no vio allí al capitán ni alférez que era el dicho teniente, que se habían ido poco delante entre los cuales iba toda las más gente que esta listada y juntos con los que tiene e que vio este testigo a Miguel de Salcedo que es el presente escribano y a Rodrigo Mendez y a otras personas que no se acuerda y vio este testigo que Rui López Calderón comenzó a dar voces y a decir que se tuviesen y comenzó a recoger los indios y gente, y en esta coyuntura volvió el dicho teniente y alférez de la ciudad a caballo hacia los ingleses, los cuales estaban con la ropa que tenían en una quebrada junto al camino.

Los cuales se retiraron porque habían tocado a recoger y no les contentaba el pillaje, y entonces bajando a lo bajo visto que no les daban el rescate que pidieron de las casas sino que las quemarían enviando a un Rivas, piloto que traían en su compañía, que lo habían asido de un navío polatico(?) de la tierra, de que se entiende tenía el inglés razón de todo lo de Payta y de la poca fuerza por ser el dicho Rivas hombre que había vivido en el puerto y los conocía a todos, el cual trató si querían rescatar el pueblo porque lo enviaba el inglés para ello, los cuales respondieron todos a una los que allí se hallaron, que no querían rescatales, que lo quemase e hiciese lo que quisiese, y en sí el Rivas no quiso volver ni quiso y le hizo una seña que no querían dende lo alto, y luego comenzaron a pegar fuego y quemaron todas las casas e iglesias salvo la casa de Gonzalo Prieto Dávila que estaba en loma por la sazón y la del dicho teniente (f.3 ) y dos o tres que tenían e lo vientos (?) podían ser las casas de la dicha ciudad entre chicas y grandes de españoles como 25 casas poco mas o menos, con sus paredes de bahareque de barro y palos y cubiertas de penca(?) salvo dos o tres casas que eran de adobes y la iglesia de los indios que servía a los espańoles, porque la otra se está labrando y el monasterio de la Merced que era asimismo de las paredes dichas y en lo que toca al poder tener el teniente más gente de los soldados que allí llegaron en los navíos y de la que estaba en la tierra que no vino a su llamado y obediencia, dijo que pudiera y haciendo diligencia y buscando que comiera y enviando por los de la tierra con más color, pudiera tener más gente y más fuerza pero que no vio que se hacía ni tenía en casa dedicada para dar de comer a los que pasaban ni detenellos ni a los que quedaron no se hacía porque vio debía de tener orden para ello el dicho teniente, ni dineros, y sabe este testigo que las mujeres e haciendo que temían los dichos vecinos y estantes mucho tiempo antes que viniese el inglés estaba apercibido y exhortado del virrey y del dicho teniente en su nombre, que las pusiesen y tuviesen la tierra adentro y ellos estuviesen a la mira 
para ver su intento del inglés y si se pudiesen defender y ofender y en si lo tenían hecho los que habían querido y el dicho teniente mandadoselo

y en sí sabe este testigo que estaba todo los más hacienda en este pueblo de Catacaos y las mujeres y alguna parte della estaba en aquella quebrada donde tiene dicho que llegó el inglés que fue un poco de vino y ropa de lo cual no llevó más de una poca plata que halló y para buscalla quebró muchas cajas y en lo que toca al haber, algunos vecinos que se adelantaron e vinieron camino deste pueblo delante sin volver atrás no sabe este testigo más de que no vio más gente de lo que susodicho tiene y algunos más que fueron volviendo, y en cuanto a tener ganas algunos de poblar a Payta por sus intereses, ha oído decir este testigo a algunos que estuvieron mejor poblados (f. 3v) en otra parte, y más a su plaza que en la dicha ciudad y puerto de Payta, ansí por la falta y costa del agua y leńa que se compra por plata, como por el peligro que corren con semejantes ocasiones.

Y esto en general los a oido a todos los más vecinos encomenderos e vivienda en este pueblo y comarca en Letera o en la presa deste río que llaman Tacala, que es la obra que a echo el dicho corregidor Alonso Forero de Ureña y de tanto valor y provecho de naturales y vecinos y estantes a esta jurisdicción y con la sacada de este río y el riego y fertilidad de este valle que se a rescatado y riega con esta obra está la tierra harta y hay lugar y tierras para todos los espanóles y naturales

y ansí a oído este testigo lo que dicho tiene y el deseo que tienen todos los más de la dicha ciudad, no se acuerda de los delanteros que se vinieron sin orden por que....(?) subieron al tablazo, caminaron los que le pareció sin resistencia de capitán y alférez, porque no había más oficiales ni los nombraron y le parece a este testigo que para la gente que era en cantidad y poca della aventajada que no pudieron hacer más ni tuvieron más orden de su capitán ni de otra persona más de que su voluntad tuvieron allí arriba, los que tiene dicho y este testigo oyó decir a muchos que si estuviera el dicho corregidor Alonso Forero presente que tuviera otra orden y más gente que no tuvo el dicho teniente y que le parece que si hubiera más gente y estuviera el dicho capitán que subcediera mejor, porque es público entre todos y que es todo lo que sabe y la verdad del caso para el juramente que fecho tiene y lo firmó de su nombre es que es de edad de más de 26 años, Juan Franco Vaca, Alonso Forero, ante mí Miguel de Salcedo, escribano nombrado (f.4).

It. E después de lo susodicho en este dicho pueblo de Catacaos en primer día del mes de Octubre de 1587 años, el dicho corregidor Alonso Forero, por ante mí el dicho Escribano para la dicha información recibió juramento de Juan Losada de Quiroga, alcalde ordinario, el cual lo hizo cumplidamente e siendo preguntado al tenor de la dicha cabeza de proceso dijo que este testigo sabe que el dicho corregidor Alonso Forero a estado ausente de la dicha ciudad de Payta y sus distritos un ańo poco más o menos y que dicen a estado en la Ciudad de los Reyes de donde llegó abrá veinte días a la dicha ciudad y a este pueblo, y este testigo oyó decir y es público que se le notificó una provisión de la Real Audiencia de los Reyes por Antonio de la Peńa, Receptor, en que decían se le mandaba saliese de la dicha ciudad y sus distritos y no entrase en ella, sin expresa licencia y el dicho corregidor, en cumplimiento de la dicha provisión salió de la dicha ciudad para la de los Reyes y ansimismo con licencia del señor virrey, con lo que se dijo a lo cual se remite, e que este testigo sabe que llegó nueva al dicho puerto de Payta y carta de su señoría del seńor virrey a Gaspar Troche de Buitrago, su lugarteniente, en que le mandaba y daba aviso de la venida de los ingleses y cuantos eran, la orden e navíos que traían y que alzase los bastimentos, vino e paños y las mujeres y plata y oro y joyas y demás haciendas que tuviesen y la metiesen la tierra adentro, atento a la poca gente que avía en ella y la poca fuerza y en cumplimiento de ello, el dicho teniente llamó a este testigo como tales y le mandó viniese a este pueblo de Catacaos por 200 caballos y 60 indios, para poner en efecto lo que su señoría del señor virrey demandaba, el cual vino a este dicho pueblo e hizo las diligencias de los caballos e indios y los espańoles que halló en este pueblo y envió a Olmos y a Piura y a otras partes por los soldados que residían en este Corregimiento y distrito y a hacer mecha para lo necesario en la guerra, y que siempre e después que el inglés corsario entró por Chile, siempre tuvieron nuevas de la llegada de Arica y Pisco y todos los puertos para acá, y el espacio y orden que traía, y los daños que hacía porque era público (f.4v) en la ciudad lo que su señoría del señor virrei avisaba por chasques, y que este testigo vió como entró el dicho corsario al 
puerto de la dicha ciudad un viernes noche 28 de mayo pasado este año y surgieron andando surcando el dicho puerto aquella noche, y la gente de la ciudad se metió en un fuertesuelo que habían hecho de palos de balsas y arena a la lengua del agua frontero de la aduana a donde estuvieron toda la noche, con mucha vigilancia y orden, y este testigo por mandado del dicho teniente y capitán salió con doce arcabuceros corriendo la costa e playa del dicho puerto por ser grande para ver si el enemigo saltaban en tierra, y ansí anduvieron todo lo más de la noche con gran vigilancia y cuidado por haber en el puerto muchas partes donde podían saltar en tierra y luego que amanecía se recogieron en el fuertesuelo y de allí vieron andar los enemigos comunicándose y sumando parecer delo que habían de hacer, porque lo veían y oyó ansí hablar por estar tan cerca del fuerte y echaron sus banderas de cuadra (?) y gallardetes a usansa de guerra y comenzaron a disparar algunas piezas de artillería al fuerte a donde estaban recogidos y luego echaron en la lancha gente y en el batel y chalupas y vinieron hacia tierra derecho al fuerte do estaban aguardando, a donde ha visto el dicho teniente la mucha gente que descubrió y venía en la lancha y bateles llamó a este testigo y le dijo que se recogiese la gente y la retirase, y así este testigo empezó a mandar retirar la gente y se retiran, y al tiempo de salir del fuerte soltaron muchas piezas de artillería, y luego vió este testigo, porque se quedó en parte solos, podía muy bien ver y contar los ingleses que en tierra saltaron de la lancha 70 hombres y de la balza y más bateles saltarían como 25 , en que por todos eran 95 e 96 y vinieron en orden en su seguimiento y llegados que llegaron hasta el pie del cerro del Tablazo y allí se detuvieron los dichos (f.5) ingleses y asimismo se detuvo este testigo y Miguel de Salcedo, que es al presente escribano y el padre fray comendador de la Merced y Pedro de Saavedra y otras personas que no se acuerda y le pidieron rescate que fue a este testigo y a los demás diciendo que rescatasen la ciudad como que la quemarían y esto decían por lengua de Ribas, un piloto que traían en su compañía, que lo habían asido en un navío que dicen que era de Bartolomé García, mercader, y a el lo respondió este testigo que hiciesen lo que quisieren, que no tenían orden para rescatar lo demás, de que eran pobres y que ganaban en quemar 25 bohíos, que eran todas las casas de aquella ciudad, y luego visto esto los dichos ingleses comenzaron a tirar muchos mosquetes y de los navíos artillería, y este testigo con los demás visto que el enemigo iba subiendo la cuesta disparando mucha arcabucería subió arriba y los demás con el, en su compañía a lo fuerte del tablazo y donde entendió se habían recogido los demás de la compañía y ciudadanos con el dicho teniente y capitán y halló a Ruy López Calderón, vecino y a Rodrigo de Mendez e Antonio de Frías y a otros dos e tres y dos frailes mercedarios y vio que andaba y a cada uno por su parte y que se venían camino a este pueblo de Catacaos y de otras partes sin orden y vio este testigo al dicho Rui López Calderón a pie y a caballo dando voces e tener e tener señores e hagamos control y andaba la gente tan desbaratada que no aprovechó y el enemigo se subió a lo alto y lo ganó y fueron como 40 o 50 personas y fueron adonde estaba alguna ropa en un quebrada y comenzaron a quebrar algunas cajas de las pocas que allí estaban y los demás enemigos haciendo escolta y sacaron lo que les parecía y lo demás dejaron, y este testigo y los demás fueron en seguimiento de los que iban delante retirados e hicieron volver algunos dellos porque e otros no parecieron que iban delante (f. $5 \mathrm{v}$ ), entre los cuales que volvieron fueron el dicho teniente y el alférez y Juan Franco y Juan de Castilla y con este testigo y los demás que tiene dicho y Alonso Ruiz hicieron rostro y acudieron a donde estaba la ropa y los enemigos se fueron retirando y dende abajo que vieron al dicho Ribas piloto a que tratase otra vez el rescate del pueblo, al cual lo subieron arriba por una barranca con mucho trabajo y se le respondió al Ribas que no querían rescatar y el dicho Ribas no quiso volver con respuesta dende que se vio fuera de sus manos y les hizo seńas con un pańo y con las manos y luego el enemigo puso fuego a todo el lugar y en breve tiempo se abrasó todo con el viento que le ayudaba, salvo dos o tres casas que quedaron, que fue la de Gonzalo Prieto Dávila y del teniente, y que en lo que toca a los vecinos y estantes que estaban presentes y se hallaron, fueron hasta en cantidad de 45 e 46 personas entre los cuales había hasta 20 hombres que podían pelear, porque los vecinos que eran 9 o 10 había un Francisco Cornejo que estaba en Catacaos por enfermo y por 80 años que tiene y Diego Vaca de Sotomayor guardando la ropa que estaría arriba de más de 70 años, Juan de Torres, estante de más de 70 años que estaba en Catacaos, enfermo, los demás fueron los 20 que tiene declarados, eran mestizos, mulatos mozos de gana- 
dos, gente de poca experiencia ni valor y ansí le parece a este testigo que le fue forzoso a hacer lo que hicieron y en lo que dice la cabeza de proceso, sí pudo haber más gente de los navíos que allí surtieron y de los de la tierra, que fueron desobedientes, y otros del término que acudieron a Saña y no vinieron a la dicha ciudad como eran obligados, se pudo juntar y tener más de 121 y el dicho teniente no lo hizo porque dijo que no tenía con que sustentallos y los vecinos lo propio, y que algunos daban orden del dicho señor virrey y socorro y municiones y que con el se le tuvieron esta suerte que tiene declarado este testigo pero que bien pudo haber más gente y haber más defensa y que el enemigo no saliera con su intención (f.6), pero que esta orden les dio el dicho teniente e capitán y esta fuerza tenían y que no hubo más de lo que dicho tiene y que en cuanto al huirse y retirarse en lo alto, algunos vecinos y estantes y no parecer ni hacer rostro y decir la cabeza de proceso y si lo hicieron por poblarse en otra parte y estar mal con la vivienda y costa de Payta y no haber tenido casa en ella dijo que el no sabe si lo hicieron por este fin e por otros motivos de los que tenían casas y habían vivido siempre en Payta, les pesaba mucho de verlas quemar y otros que no tenían casas ni son aficionados a vivir en ella no los vio allí como dicho tiene e que esto es la verdad de lo que sabe y pasa en el caso e que este testigo tiene su dicho en cierta información que se hizo a pedimento del monasterio y convento de la Merced, sobre quema del dicho monasterio, y que se entienda este susodicho y el otro ser todo uno, porque su intención no ha sido más de decir la sustancia y caso como pasó y lo firmó de su nombre e que es de edad de más de 30 años e no le toca ninguna de las generales, leyose el susodicho rectificose Juan Losada de Quiroga, Alonso Forero, ante mí Miguel de Salcedo, escribano nombrado (f.6).

E después de lo susodicho en el dicho pueblo de Catacaos en primero de Octubre de 1587 años, el dicho capitán Alonso Forero, corregidor e justicia mayor, para la dicha información, hizo parecer ante sí a Juan García de Escobar, del cual tomó e recibió su juramento en forma de derecho y lo hizo cumplidamente, e siendo preguntando al tenor de la dicha cabeza de proceso dijo, que este testigo sabe cómo el dicho corregidor salió de la ciudad de Payta para los Reyes, atento a que se le notifica por A(?) Rodríguez Peña, recepta una provisión de la Real Audiencia de los Reyes para que saliese de la ciudad y su jurisdicción y no entrase cual sin su expresa licencia, y asimismo sabe este testigo que salió el capitán Alonso Forero con licencia del visorrey para ir a la Ciudad de los Reyes y atento haberse mandado salir deste distrito y a tratar negocios de la Real Hacienda y otras obras de la república que le dejó encargadas y a estado ausente y detenido por la Real Audiencia, a pedimento de Juan Alonso de Albuijar y sus consortes, por sus pasiones, y el estuvo en ella ausente casi un año y que sabe este testigo que estando en la dicha Ciudad de los Reyes el dicho corregidor llegó la nueva de que como habían entrado los ingleses corsarios en esta mar e luego el visorrey que vio la nueva dello y razón de los que había por todos los puertos y a la dicha ciudad y puerto de Payta y Tierra Firme y Nueva España, y asimismo que vió el dicho señor visorrey a Gaspar Troche de Buitrago lugarteniente del dicho corregidor para que hiciese prevención conforme a la orden que le dio (?) y asimismo que metiese la tierra adentro a las mujeres, plata, joyas y bastimentos y que anduviesen a la mira los vecinos y estantes de la dicha ciudad para saber y defender y ofender al enemigo, y asimismo sabe este testigo por las nuevas y chasques que envió el dicho señor visorrey que habían llegado los ingleses corsarios a Arica y lo que subcedió en ella y entonces entendió viniera el dicho corregidor con uno de estos avisos y poner cobro(?) en su corregimiento e puerto como hombre que tiene experiencia y sabe.

Asimismo que vinieron por toda la costa y a otros puertos y a Pisco y pasaron abajo haciendo los daños que pudieron y de todo tuvieron aviso en la dicha ciudad: el dicho Gaspar Troche de Buitrago por el dicho señor virrey y en Chérrepe tomaron el navío de Antonio Suarez de Medina y el de Bartolomé García y en el dicho navío de Bartolomé García que había salido de Payta tomaron a Ribas piloto que le supieron de que había en Payta, todo lo que entendió por el suceso y lo trajeron consigo y llegaron al puerto de Payta a los 29 de mayo y el día que llegaron sobretarde entraron por el puerto al anochecer y a lo que parece surgieron en el tres navíos y un patache y una lancha, y la gente del lugar que serían hasta 45 personas vecinos y estantes y llegadizos mestizos y mulatos de todos ellos.

La cantidad dicha y asimismo cuatro vecinos dellos muy viejos como ya no había, y se pusieron en 
un fuertesuelo de madera y arena que tenían para el efecto a la lengua del agua frontero de las casas de la aduana que es en medio del puerto, y estuvieron cual con mucho recato y grombela (?) toda la noche y echando arcabuceros fuera a rondar la costa y algunos hombres de a caballo y estuvieron con mucho ánimo hasta el día porque entendían según las nuevas no eran mas de hasta 90 ingleses y entendieron no saltarían en tierra con tanta gente y ventaja y venida la mañana se comenzaron a comunicar los enemigos de unos navíos a otros a lo que pasaban para echar bandera de cuadra y por los (?) y (?) y como se entiende supieron la gente que estaba de arriba que se lo pudo decir por ser de allí y avello visto se determinaron a cañoneallos desde los navíos y lancha y echaron por dos e tres partes gente en tierra con la lancha y bateles en que echaron más de 90 hombres arcabuceros y mosqueteros y piqueros y visto por el dicho teniente y los demás acordaron por la mucha fuerza que conocieron del enemigo y la ventaja de armas y munición y por la flaqueza de arma y una parte de la gente de la ciudad que no había hasta 20 hombres e 25 que pudiesen pelear de retirarse a lo fuerte y alto del tablazo donde entiende este testigo que se defendieran sino se desbaratan y salieron de orden por culpa de algunos que se adelantaron allá arriba y el enemigo los fue siguiendo y tirando en su seguimiento mucha arcabucería y algunas piezas de los navíos y lancha que alcanzaba allá arriba.

y en efecto, en subiendo a lo alto o al pie de el quedó alguna gente de la ciudad e iban hablando con el inglés, el cual les pidió rescate y ellos no aceptaron entre los cuales conocido estaban Rui López Calderón y hermanos suyos e Juan de Quiroga e Miguel Salcedo $\mathrm{y}$ otras gentes que por ir un poco adelante no echo deber y vió este testigo que algunos de los vecinos iban sin orden y no aguardaron en el fuerte del tablazo ni llevaron orden y ansí no vio este testigo los que quedaron ni si volvieron (f. $7 \mathrm{v}$ ) más que oyó decir este testigo e otro día como habían quedado allí algunos y vieron quemar el lugar pero los demás vio como Gaspar de Valladolid e Pedro de Saavedra fueron los primeros y no les dio pena: que se quemase el lugar porque se les oyó decir al dicho Pedro de Saavedra ese testigo y sabe que viven de mala gana y por fuerza en la dicha ciudad y le tienen al dicho corregidor mucho odio porque los hace asistir en sus vecindades y sabe este testigo que tras de ellos vinieron otros muchos a este pueblo de Catacaos, y oyó decir este testigo que Gaspar Troche de Buitrago volvió con su alférez a voces que les dieron, vengan señores y que acudieron algunos a donde estaba la ropa, en una quebrada, en el camino donde que los ingleses quemaron los que les pareció y se volvieron a la playa y en lo que toca a móvil (?) e coger semejante ni detener la (?) allí de los navíos y llegar toda la del distrito, entiende este testigo que hubo descuido y flojedad por causa de no dadle de comer ni tener municiones ni abelas enviado socorro ni orden para ello, ya sabe que los vecinos no dieron ni quisieron dar de comer a ninguna persona por orden del teniente ni a obedecedle ni la gente que se fue a Sańa del distrito, no era justo que fuera $y$ otros que se fueron y lo tuvieron en este pueblo de Catacaos y todo fue de conformidad y poca obediencia al teniente porque con la ausencia de su corregidor y capitán y la mala gana que tenían de vivir en Payta ninguno, todo muy sin orden y que todo fue general el no obedecer al dicho teniente y ansí se desbarataron todos por haber muchos pareceres y por la falta de cabeza y no estar prevenidos de gente y municiones como tiene dicho y esta es la verdad y lo que sabe hace juramento que fecho tiene y lo firmó de su nombre y que es de edad de más de 37 años, leyósele sin dicho rectificose, que a que por lo que tiene dicho se entiende que los ingleses pegaron fuego a la dicha ciudad de Payta y la quemaron porque (f. 8) no quisieron rescatadla por ninguna cosa y que oyó decir el testigo que había venido de parte de los ingleses a pedir rescate y como allí que se quedó con la gente que estaba en lo alto de la ciudad y asistió este testigo cuando dió la vuelta arder la ciudad, que eran hasta 25 casas poco más o menos y que no quedaron más de dos casas, del teniente y otra del tesorero Gonzalo Prieto, porque el aire le ayudó a no quemarse y lo firmó de su nombre y el señor corregidor Alonso Forero, Juan García Escobar, ante mí Miguel de Salcedo, escribano nombrado.

E despues de los susodicho, en este dicho pueblo de Catacaos en dos días del mes de Octubre de 1587 años, el dicho corregidor Alonso Forero, por ante mí el dicho escribano hizo parecer ante mí a Gonzalo Farfán, vecino desta dicha ciudad de Payta, del cual se recibió juramento en forma de derecho e lo hizo cumplidamente, e siendo preguntado al tenor de la dicha cabeza de proceso dijo que de los que dello sabe es que puede haber un año poco más o menos que 
vido salir de Payta al dicho corregidor para la Ciudad de los Reyes a donde se decía públicamente iba por mandado de los señores de la Real Audiencia de los Reyes y de donde dicen a estado hasta puede haber 20 días poco más o menos, que llegó a la dicha ciudad de Payta e que estando ausente del dicho pueblo de Payta el dicho corregidor vino nueva de ingleses había venido a Chile. Lo cual se supo en Payta por carta del señor virrey y de otros vecinos que escribió e recibió el teniente de corregidor Gaspar Troche de Buitrago, a quien a visto por teniente de corregidor en la dicha ciudad desde que el dicho corregidor es corregidor en la dicha ciudad e que sabe que el dicho inglés corsario llegó al dicho puerto de Payta habiendo habido nueva primero en la dicha ciudad de que había tocado en otros dos o tres puertos allá arriba y que llegó al dicho puerto de la ciudad de Payta, viernes que como que (f.8v) no se acuerda cuantos del mes más de que se sabía al estante amanecieron surtos en dicho puerto, en un galeón grande y dos navíos pequeños y una balsa y dos botecillos pequeños, $\mathrm{y}$ este testigo con la demás gente que había en la dicha ciudad estuvieron toda aquella noche juntos y en vela en las casas reales, acudiendo de allí a otras partes a hacer velas y centinelas porque el dicho enemigo no saltasen y los cogiesen descuidados y otro día por la mañana sábado se estuvieron todos en una trinchera que costaba y había mandado hacer el dicho teniente delante de las casas reales con la lengua del agua, que era de 40 hombres viejos y mozos de todas suertes que eran y allí estuvieron con mucho riesgo por causa de la artillería con que les tiraron, de que una pelota de ella de hierro colado tan grande como una naranja grande dió en el propio baluarte, de donde la sacaron y enviaron al virrey, y estuvieron más de tres horas hasta que los dichos ingleses salieron en una lancha y la balsa y otros botecillos mucha cantidad dellos que serían como hasta 100 ingleses poco más o menos, como después parecían porque los contaron al saltar en tierra y visto por el dicho teniente como venían a tierra y tanta cantidad de gente y que los dichos navíos se habían puesto a punto para batir la ciudad con la artillería y tiraron a la gente como había comenzado a hacer y que no había fuerza ni gente para los poder resistir ni defender, les mandó a este testigo y a los demás que se retirasen y subiesen a los altos de las barrancas como lo hicieron todos y subidos a lo alto les mandó el dicho su teniente hiciesen alto y aguar- dasen para defender la ciudad y así aguardaron hasta que de allí trataron los ingleses de abajo y españoles de arriba rescatasen la ciudad y que no la quemarían y habido concejo de lo que se había se resumió en decir no convenía rescatarse por no dar fuerzas al enemigo (f.9) en dadles plata porque de lo que se dé servirá (?) y el virrey y que menos inconveniente era que lo quemasen que Su Majestad en cuyo servicio se hacía daría después con que podedlla redificar a su costa y ansí vista esta respuesta por los dichos ingleses acometieron (?) e hicieron retirar a los nuestros y que no sabe quiénes fueron los primeros que huyeron más de que este testigo y otros siete u ocho compañeros se retiraron a tiempo de que el dicho teniente y el alférez y los demás se habían ya retirado y por verse pocos hicieron lo propio a tiempo de que ya lo enemigos venían tan cerca como a una cuadra dellos donde este testigo corrió mucho riesgo por estar muy enfermo y averse causado y no poder huir y que sino fuera por un esclavo suyo que le trajo un caballo en que irse y le subió, que le cogían y que de los siete u ocho que quedaron con este testigo se acuerda eran el alcalde Juan de Quiroga y Antonio de Frías y Rodrigo de Mendez y Alonso Ruiz y Rui López Calderón, y que lo demás no se acuerda bien quienes eran y que sabe que los ingleses quemaron la dicha ciudad y las demás casas de los espańoles, que no quedaron más por quemar de tres casas, dos del teniente y una de Gonzalo Prieto y que no sabe quiénes fueron los que desampararon la ciudad porque la quemasen para ponerse a vivir a Catacaos ni tal a entendido antes le parece cosa que no se puede creer porque dejar nadie su casa y puertas y muchas alhajas y otras cosas de valor a que las quemaran, para el dicho efecto le parece a este testigo no se puede creer y que si algunos estuvieron con ese propósito e intención pudieron lo salvar todo y pues no lo salvaron y se les quemó, entiende no estarían con este propósito sino antes de defendello y que este testigo despues de todo lo susodicho como tiene dicho por averse visto y quedado tan fatigado y causado por su enfermedad y vido que alcanzó al dicho teniente adelante hacia este pueblo por el camino que viene (f. 9v) a el que no le dijo este testigo que aguardase ni que habían de aguardar y que todos venían andando así a este pueblo de Catacaos y porque hacía sol y traía al costado de su caballo al Comendador de la Merced, se adelantó para llegar a la ramada que está en el camino y a guardar allí al 
dicho teniente y a los demás que venían y avistose y tan solo se llegó hasta este pueblo de Catacaos aquel propio día sábado y sabido por este testigo que el teniente se quedaba en el pueblo y no venía ni había de venir por entonces volvió este testigo luego otro día domingo por la mańana al dicho pueblo de Payta a ver si era menester su ayuda para algo y llegó aquel propio día al dicho pueblo y habló con el dicho teniente con estar tan malo como estaba y que no sabe quiénes lo fueron rebeldes en cumplir el mandado del dicho teniente en no ir a la defensa de la dicha ciudad ni tampoco porque no se recibieron de gente ni municiones porque no era a su cargo sino del dicho teniente que dará cuenta dello e que se contiene en lo su dicho, que una probanza que hizo el Comendador de la Merced de la casa de Payta frai Gaspar Farías, en donde más particularmente dijo su dicho sobre este caso al cual se remite lo cual es la verdad y lo que sabe y de presente se le acuerda para el juramento que tiene fecho y lo firmó en su nombre y siéndole leído se rectificó que es de edad de más de 38 años, Alonso Forero, Gonzalo Farfán, ante mí Miguel de Salcedo, escribano nombrado.

Ytem, después de lo susodicho en este dicho pueblo de Catacaos en dos días del dicho mes de Octubre de 1587 ańos el dicho corregidor Alonso Forero para la dicha información como e recibió juramento en forma de derecho de Rui López Calderón, vecino de la dicha ciudad de Payta e lo hizo cumplidamente e siendo preguntado al tenor de la dicha cabeza de proceso dijo, que este testigo vido como el dicho corregidor a más tiempo de un año que salió deste pueblo de Catacaos para la dicha Ciudad de los Reyes y porque le vido ir por el mismo camino que van a la dicha Ciudad de los Reyes y es público y no varió el estado en la dicha Ciudad de los Reyes el dicho tiempo por causa que se notificó una provisión real para que saliese de su corregimiento y no entrase a el sin licencia de los señores de la Real Audiencia a donde aceptado siguiendo ciertos pleitos y este testigo tiene para sí que si le hubieran dado antes de ahora licencia para volver a su corregimiento lo hubiera hecho, y asimismo este testigo oyó decir al dicho corregidor tenía carta y licencia del señor virrey Conde del Villar para poder ir a la Ciudad de los Reyes y dejar su teniente en su lugar, y que estando el dicho corregidor en la Ciudad de los Reyes este presente año vino nueva de que habían entrado los ingleses corsarios en el Mar del Sur y así se tuvo nuevas en la ciudad de Payta dello por aviso que tuvo Gaspar Troche de Buitrago, teniente de corregidor dada por el señor visorrey Conde del Villar y ansí el dicho teniente hizo juntar la gente que en este pueblo de Catacaos había y llamó a los vecinos encomenderos que de presente estaban en esta jurisdicción y entre ellos este testigo como tal vecino se halló y estuvo en la dicha ciudad hasta que el enemigo llegó viernes a medianoche 28 de mayo deste presente ańo y antes de su llegada se tuvo nueva y aviso de a donde el enemigo llegaba, la cual tenían muy a menudo ansí del señor visorrey como de los demás corregidores y otras personas por venir el dicho inglés muy despacio, el cual enemigo traía tres navíos grandes y un barco con una lancha y sus bateles, y el sábado siguiente 29 de mayo a las 9 del día, poco más o menos desembarcaron al parecer este testigo de 90 a 100 hombres en tres o cuatro partes, y la gente que en la dicha ciudad de Payta había que serían como hasta cuarenta hombres poco más o menos, estaban metidos en un fortecillo o trinchera que el dicho teniente hizo hacer delante de las casas reales, los cuales viendo ser pocos en número y mal armados y sin tener socorro de parte alguna por mandado del dicho teniente y por parecer de algunas personas por no ser parte para defenderse ni ofender al enemigo se subieron (f. 10v) a lo alto de las barrancas a donde se hizo alto y se comenzaron a arcabucear con los ingleses, los cuales ganaron el alto por ser muchos y los que el teniente tenía, aunque eran como dicho tiene cuarenta personas, los diez indios, personas de los que no eran para pelear, por ser de poca experiencia y mozos y ansí se retrujeron y solamente quedaron solos postreros Gonzalo Farfán e Juan de Quiroga y Rodrigo de Mendez y el presente escribano y Alonso Ruiz y Antonio Frías y Gabriel de Miranda e otras personas, y que todos ellos no había más vecinos encomenderos de siete $\mathrm{u}$ ocho y los tres viejos impedidos por su edad y sí algunas personas en sí vecinos encomenderos como las demás personas se vinieron a este dicho pueblo e puerto de Payta por haberlo los dichos ingleses quemado las casas iglesias que aún había excepto tres o cuatro y estos no fuera posible defender no se quemaron pues la gente que en la dicha ciudad había era tan poca y este testigo tiene para sí que si se recogiera algunas personas, que en unos navíos en aquella sazón al dicho puerto llegaron o de otras partes e hubieran venido a favorecer 
y socorrer la dicha ciudad no subcediera el incendio ni ruina de el y que si el dicho teniente no los recogió e detuvo no sabe este testigo la orden que el visorrey Conde del Villar había dado al dicho teniente más de que vio que se fueron de la ciudad todos los que con los navíos habían venido y no vinieron muchas personas de la jurisdicción sino antes fueron los que estaban en el pueblo de Motupe a la villa de Saña y siempre vio que obedecían al dicho teniente Gaspar Troche de Buitrago, por lo que les mandaba y poco sabe y es la verdad por el juramento que fecho tiene y lo firmó en su nombre e que es de edad de 46 ańos, Alonso Forero, Rui López, ante mí Miguel Salcedo, escribano nombrado (f. 11).

Yt. En este pueblo susodicho, en esta ciudad de San Francisco de Buena Esperanza del puerto de Payta, en seis días del mes de Octubre de 1587 ańos, el dicho corregidor Alonso Forero Ureña, para la dicha información como e recibió juramento en forma de derecho de Rodrigo de Mendez, regidor desta ciudad, el cual lo hizo cumplidamente y siendo preguntado al tenor de la dicha cabeza de proceso dijo, que lo que sabe es que este testigo vió como el dicho corregidor Alonso Forero salió desta ciudad abrá un año poco más o menos, y a lo que se decía para la Ciudad de los Reyes (cuando) es público aceptado hasta abrá veinte días poco más o menos que vino de la dicha ciudad e que este testigo oyó por público como los señores de la Real Audiencia de los Reyes le mandaban salir desta ciudad y su distrito porque venía un receptor contra el a hacer cierta información a pedimento de Juan Alonso y Lázaro Giraldes.

E este testigo sabe cómo estando el dicho corregidor en la Ciudad de los Reyes vino nueva a esta ciudad por haberlo enviado Su Excelencia a Gaspar Troche de Buitrago, teniente del dicho corregidor en que daba aviso como habían entrado los ingleses en esta Mar del Sur, y oyó este testigo le habían enviado mandar sacasen haciendas y mujeres desta ciudad, la tierra adentro, y así en cumplimiento della vio este testigo como el dicho teniente hizo decir a todas las mujeres que había en este pueblo y las haciendas que tenían, y asimismo oyó decir su señoría del virrey había enviado aviso della a Panamá y Nueva España y otras partes, y que este testigo no sabe la orden que su señoría del virrey envió al dicho teniente en lo que había de hacer tocante a la defensa desta ciudad e que este testigo sabe cómo cada día había poco días que se dejase de tener chasque y aviso de Su Excelencia, de como el dicho inglés había tocado en dos puertos de Chile, Arica, Pisco y así como venía bajando siempre hubo aviso del dicho virrey e otras personas hasta que llegó a este puerto:

Y de la toma de los navíos y daños que venían haciendo e que este testigo se halló en esta ciudad e puerto cuando los dichos ingleses entraron con la demás gente que había en este pueblo para la defensa de el e vio que un viernes 28 de mayo (f. $11 \mathrm{v}$ ) tuvieron aviso por los centinelas de haber visto los navíos del enemigo y todos con orden del dicho Gaspar Troche de Buitrago: toda aquella noche estuvieron en vela en las Casas Reales y un portezuelo de madera y tierra que habían hecho a la lengua del agua, porque el enemigo no saltase en tierra sin que se viese e se enviaron a estos arcabuceros repartidos por toda la playa, casi una legua de trecho por haber muchas partes y poder los enemigos saltar y cuando este trecho estuvieron como dicho tiene en vela toda la noche hasta que amaneció porque la Armada del enemigo estaba en el puerto que entró dos e tres horas después que anocheció y después que fue de día vio este testigo como los navíos del enemigo eran tres, un galeón grande y un almiranta y otro navío pequeño y una zabra y una lancha y la capitana soltó la bandera del topo con cruz colorada y luego abajo en la popa de la capitana soltó su bandera de cuadra y sus gallardetes muchos que traía la dicha capitana y cruzó las chenteras (?) con los mástiles aviso de batalla e vió este testigo como envió aviso en un batel muy pequeño donde iban tres hombres solos y lo que parecían a dar aviso a la almiranta y capitana para echar gente en tierra, porque luego vieron como del galeón salió la lancha con hasta 60 o 75 hombres y el propio general en otro barco con otros 30 hombres poco más o menos, todos estuvieron en el fuertesuelo viendo la orden que daba el enemigo e tiró la capitana un tiro grande y dio en el propio fuerte con una pelota de hierro colado como una naranja bien grande y otro que no llegó al fuerte pasando alto como dicho tiene.

Estaban todos en el fuerte con sus arcabuces y armas hasta que el dicho Gaspar Troche de Buitrago mandó retirar la gente, vista la pujanza del enemigo y la notable ventaja de la gente que parecía venía en la lancha y bateles del enemigo y la poca que había en la defensa de la tierra, que serían como 45 per- 
sonas y entre ellos (f.12) pudieron haber hasta $25 \mathrm{e}$ 30 personas que pudiesen pelear, porque los demás eran muy viejos y otros muchachos e mulatos, gente bisońa e de poca experiencia y así se salieron de la dicha trinchera con orden y concierto del dicho teniente y la demás gente a tomar el alto de las barrancas arriba sin que hubiese desconcierto entre la gente aunque los iban cañoneando con la artillería y con este concierto se subieron al alto y pasaron allí con designio de defender el paso al enemigo si quisiese subir, como muchas veces lo había echo y significado el dicho teniente a toda la gente lo habían de hacer en caso que se viese que no había defensa bastante para defender al enemigo que no saltase en tierra en la dicha lancha y bateles y los iban contando como iban saltando y fueron 95 o 96 personas poco más o menos, los cuales luego vinieron al pie de la barranca y echaron una bandera pequeña blanca de paz y por lengua del Gonzalo Ribas, piloto de esta mar que habían asido del navío nombrado La Cuaza(?) Grande, a voces pedían rescate e que no quemarían la ciudad y el dicho teniente dijo que no daría cosa ninguna de rescate, que hiciecen lo que quisiesen, $y$ con esta respuesta algunos de los nuestros saltaron y dispararon sus arcabuces contra los enemigos, los cuales también respondieron con su mosquetería, apuntando a los que estaban en un alto sobre ellos, con quien hablaban y juntamente su sola artillería gruesa y los que estaban en lo alto se bajaron a la parte donde estaba la demás gente, a un paso y visto por los enemigos acometieron a ganar el alto y la ganaron, donde sojuzgaban la poca gente que habían de los nuestros, donde se halló este testigo y oyó decir al dicho teniente a voces aquí, aquí señor, y en esto los enemigos venían de golpe y este testigo y Antonio de Frías y Alonso Ruiz y otros dos o tres personas que no se acuerda bien cuantos eran vistose con los enemigos que venían tras el dicho a tiro de arcabuz y menos dispararon sobre ellos sus arcabuces y visto que no les daban lugar a cargar sus arcabuces y el poco socorro que tenían porque se iban retirando. Los demás se retiraron todos y los enemigos tras ellos y llegaron los enemigos que le parecían los que subieron como 40 hombres y echaron una piña(?), bajaron a una quebrada donde estaban unas cajas y otras mercaderías y quebraron las cajas y este testigo con el dicho teniente e Juan de Quiroga y Gabriel de Miranda, alcaldes y Rui López Calderón e Diego de
Grajeda, alférez y el padre del comisario fray Pedro Martínez y el presente escribano volvieron a caballo hacia donde estaban los dichos enemigos, los cuales habiendo descubierto la gente de a caballo que volvía se retiraron y bajaron luego al pueblo donde estaban los demás enemigos que habían saltado y este testigo $\mathrm{y}$ los que dicho tiene se quedaron en lo alto y de allí vio este testigo que los enemigos que vieron otra vez al dicho Gonzalo de Rivas a tratar del rescate, y el dicho teniente dijo siempre que no daría un real de rescate y ansí el dicho Gonzalo de Ribas, de una de las barrancas hizo señas con su sombrero que no querían y luego vio este testigo y los demás como pusieron fuego a las casas del pueblo y las quemaron y barazaron todas, que no quedaron sino dos o tres y serían las casas que se quemaron y había hasta 15 o 20 casas de paja e que este testigo sabe que el dicho teniente envió por gente de la jurisdicción y la que se pudo haber visto por el dicho habían e faltaban y de la tierra envió al alguacil mayor desta ciudad e no vino a tiempo e que este testigo no sabe ninguna persona desease se le quemase su casa por despoblar el pueblo, sino que se hizo toda la defensa posible por defenderla e que este testigo no se acuerda de las personas que se retiraron de los primeros más de lo que dicho tiene e que esto es la verdad y lo que sabe y vió para el juramento que tiene fecho y lo firmó en su nombre e que es de edad de 50 años poco más o menos e siéndole leída su dicho se rectificó, Alonso Forero, Rodrigo de Apraez, ante mí Miguel de Salcedo, escribano nombrado.

Yt. En este pueblo (f.13v) de lo susodicho en esta dicha ciudad de San Francisco de Buena Esperanza del puerto de Payta en seis días del mes de Octubre de 1587 años, el dicho corregidor Alonso Forero Ureña para la dicha información como e recibió juramento en forma de derecho de Antonio Frías, mercader, vecino desta ciudad e lo hizo cumplidamente e siendo preguntado al tenor de la dicha cabeza de proceso dijo, que este testigo sabe que el dicho corregidor Alonso Forero salió desta ciudad había un año poco más o menos, y a lo que decían para fuera de la jurisdicción, ello pues oyó decir había ido a la Ciudad de los Reyes donde dicen a estado hasta habrá 20 días poco más o menos que llegó a esta ciudad e que fue público en esta ciudad que se notificó al dicho corregidor Alonso Forero un receptor que vino de la Real Audiencia de los Reyes y es una provisión 
en que mandaba saliese desta ciudad y su distrito y no entrase en ella hasta tanto que se viese su causa por la Real Audiencia y no sabe este testigo tuviese licencia de su señoría del Conde del Villar visorrey destos reinos para ir a la dicha Ciudad de los Reyes e que este testigo sabe como su señoría el Conde del Villar sabía la nueva de los ingleses, despachó aviso al dicho Gaspar Troche de Buitrago como era cierta nueva de corsarios y que hiciese sacar las mujeres e haciendas e comidas desta ciudad a la tierra adentro y ansí en cumplimiento dello el dicho teniente lo hizo quedando el dicho teniente nombrado por el dicho corregidor y oyó decir este testigo como el dicho visorrey envió aviso a Tierra Firme y a Nueva Espańa y otras partes y fue público su (?) del dicho virrey que dio orden al dicho teniente de lo que había de hacer e que este testigo sabido como por el dicho virrey se tenía nueva y aviso de haber tocado el dicho corsario en los puertos de Chile, Arica, Pisco y casi los más días y noches había chasques y avisos del dicho virrey e de otras personas dando cuenta (f.14) de lo que hacían y los dańos y tomas de navíos y el número de gente que traía e que este testigo sabe que un viernes noche que se contaron 28 de mayo deste año vino entrando la Armada del enemigo corsario porque este testigo como persona que se ejercitaba cada día en ir a ver la costa y los centinelas que en ella había los vio venir y luego dio aviso al dicho teniente Gaspar Troche de Buitrago y luego toda la gente del pueblo se puso en orden en las Casas Reales y de Aduana y a horas de la oración el dicho teniente envió a este testigo ofreciéndose a ello una legua de aquí por la playa con indios para saber cuándo entraba el enemigo e cuantos navíos y si daba orden de echar la gente en tierra y así estuvo este testigo toda la noche hasta medianoche y vino este testigo al dicho teniente a saber si había nueva y orden de guerra y dadle cuenta de los navíos que venían entrando en el puerto y el dicho teniente dijo que volviese otra vez a la dicha centinela y ansí volvió hasta el cuarto del alba que envió a llamar y así estuvo este testigo en el cuerpo de guardia que se hacía hasta que amaneció, todos en vela con sus arcabuces y mechas encendidas, los cuales tenían, y después que amaneció vió este testigo como el enemigo tenía surtos en triángulo tres navíos, capitana y almiranta y otro navío y una balsa que la apegaron en tierra junto al cuerpo de guardia para poder ofender la gente que estaba en tierra y defender la gente inglesa que ellos echasen con la lancha como lo echaron y que este testigo vio como estuvieron toda la gente de guardia hasta dos horas (?) del día en el fuertezuelo de madera que estaba hecho a la lengua del agua y esperaron a que lo bombardeasen el enemigo y el (f. 14v) dicho teniente vio como el dicho corsario echaba fuerza de gente en la lancha y dos bajeles y la poca gente que había que serían como hasta 45 o 46 personas y que ante todo no había 25 personas de pelea por haber 6 o 7 hombres viejos y muchos mozos de ganado y gente bisoña y moza y haber poca munición, porque por falta della se deshizo la pieza de los órganos de nuestra señora de las Mercedes y a esta causa y porque les comenzaron a cańonear por orden del dicho teniente se retiraron a la barranca del tablazo donde entendió este testigo se hicieron fuertes y subido que fueron este testigo se quedó atrás y se halló con algunas personas que fueron Juan de Quiroga y el padre Comendador de la Merced y otras personas porque los demás iban adelante y de allí vio este testigo y los demás que estaban con el cómo saltaron los dichos ingleses en tierra y eran al parecer este testigo como hasta 95 o 96 personas por todos porque los contaban como iban desembarcando y los vio venir en demanda del tablazo y allí pidieron rescate por un Gonzalo de Ribas que es el piloto que traian y se entiende les metió en este puerto porque era de aquí y lo traian cautivo, que lo habían asido del navío de Antonio Suarez de Medina, el cual dicho Ribas trató dello diciendo señores rescatense a mi y a este pueblo y a estas iglesias por amor de Dios, miren que son luteranos estos y an de quemar el pueblo, y a esto respondió el alcalde Juan de Quiroga, que no querían rescatarlo ni tenían orden para ello y viendo esto los ingleses vinieron tras ellos por la propia cuesta tirándoles muchos arcabuzazos y de la mar artillería y este testigo se fue retirando y estando haciendo rostro y habiendo disparado a los enemigos cuatro veces y volviendo a cargar su arcabuz vio que andaba toda la mas de la gente sin orden y así se retiraron todos porque iban unos tras otros y los dichos enemigos (f.14v) ganaron el alto y viniendo tras ellos hasta una quebrada donde estaban algunas cajas y ropa y allí quebraron los ingleses algunas cajas y rompieron fardos y petacas adonde faltó muchas cosas e después vió este testigo a Rui López Calderón y al contador Gabriel de Miranda y a Juan de Quiroga decir hagan alto caballeros, tenganse, tenganse e fue el dicho Ruiz López Calderón 
adelante dando estas voces y visto que no volvían este testigo se fue hacia el pueblo de Colán porque vió que algunos estaban a caballo e iban hacia Catacaos y este testigo se hallaba en una mula y fue hacia Colán como dicho tiene que está cerca, a dar aviso del suceso a los indios y gente que allí estaba para que se pusiesen los indios encobro(?) entendiendo que el enemigo echará gente de la otra banda por el dicho pueblo de Colán e hizo quitar las cruces del camino y del dicho pueblo de Colán vio arder las casas desta ciudad, la cual se quemó y arruinó toda salvo tres o cuatro casas que quedaron por quemar con el pueblo de los indios que no se quemó y en lo que toca a los rebeldes que no acudieron a esta necesidad, que no sabe si los que quedaron fueron llamados o no o quiénes son, que lo dirá el teniente e las personas que fueron nombradas para llamallos, porque este testigo no tuvo más cuenta de con su arcabuz acudir a lo que le mandaron y a la mayor necesidad e que esta es la verdad y lo que sabe para el juramento que fecho tiene y lo firmó en su nombre y que es de edad de más de 32 años y siéndole leída su dicho se rectificó en él, Alonso Forero, Antonio de Frías, ante mí Miguel de Salcedo, escribano nombrado, (?) vale.

Yo el dicho Miguel de Salcedo, escribano nombrado (?) presente a lo que dicho y de mandamiento del dicho capitán Alonso Forero Ureña corregidor que aquí firmó su nombre Alonso Forero, escribano estas quince fojas de papel con esta y firma. Miguel de Salcedo (?). 